\title{
A dynamic factor model for the Mexican economy: are common trends useful when predicting economic activity?
}

\author{
Francisco Corona ${ }^{1}$ (D) - Graciela González-Farías ${ }^{2}$ • \\ Pedro Orraca ${ }^{3}$
}

Received: 26 January 2017/Revised: 6 August 2017/ Accepted: 30 August 2017/

Published online: 15 September 2017

(C) The Author(s) 2017. This article is an open access publication

\begin{abstract}
In this paper we propose to use the common trends of the Mexican economy in order to predict economic activity one and two steps ahead. We exploit the cointegration properties of the macroeconomic time series, such that, when the series are $I(1)$ and cointegrated, there is a factor representation, where the common factors are the common trends of the macroeconomic variables. Thus, we estimate a large non-stationary dynamic factor model using principal components (PC) as suggested by Bai (J Econom 122(1):137-183, 2004), where the estimated common factors are used in a factor-augmented vector autoregressive model to forecast the Global Index of Economic Activity. Additionally, we estimate the common trends through partial least squares. The results indicate that the common trends are useful to predict Mexican economic activity, and reduce the forecast error with respect to benchmark models, mainly when estimated using PC.
\end{abstract}

Keywords Dynamic factor models - Common trends · Factor-augmented vector autoregressive model $\cdot$ Partial least squares $\cdot$ Forecast error

Francisco Corona

fcorona@est-econ.uc3m.es

Graciela González-Farías

farias@cimat.mx

Pedro Orraca

porraca@colef.mx

1 Departmento de Estadística, Universidad Carlos III de Madrid, Calle Madrid, 126, 28903 Getafe, Madrid, Spain

2 Centro de Investigación en Matemáticas, A.C., Jaliso s-n, Mineral de Valenciana, 36240 Guanajuato, Guanajuato, Mexico

3 Departamento de Estudios Económicos, El Colegio de la Frontera Norte, Carretera Escénica Tijuana-Ensenada Km 18.5, 22560 Tijuana, Baja California, Mexico 
JEL Classification C38 $\cdot$ C53 $\cdot$ E00

\section{Introduction}

In recent years, due to the availability of data on a vast number of correlated macroeconomic and financial variables collected regularly by statistical agencies, there has been an increasing interest in modeling large systems of economic time series. Therefore, econometricians have to deal with datasets consisting of hundreds of series, thus making the use of large dimensional dynamic factor models (DFMs) more attractive than the usual vector autoregressive (VAR) models, which usually limit the number of variables; see Boivin and $\mathrm{Ng}$ (2006). DFMs were introduced by Geweke (1977) and Sargent and Sims (1977) with the aim of representing the dynamics of large systems of time series through a small number of hidden common factors, and are mainly used for one of the following two objectives: first, forecasting macroeconomic variables and second, estimating the underlying factor in order to carry out policy-making (e.g., the business cycle; lagging, coincident, and leading indicators; or impulse-response functions, among other aspects). Another interesting application is to use the common factors as instrumental variables or exogenous regressors in panel data analysis. See Bai and Ng (2008), Stock and Watson (2011), and Breitung and Choi (2013) for a review of existing literature and applications of DFMs.

Note that macroeconomic time series are generally non-stationary and frequently cointegrated; see, for example, Kunst and Neusser (1997). On the other hand, a cointegrated system can be expressed in terms of a factor representation; see Stock and Watson (1988), Vahid and Engle (1993), Gonzalo and Granger (1995). Furthermore, these authors show that the common factor representation implies that the variables of the system are cointegrated if the common factors are $I(1)$ and the individual effects are $I(0)$. However, in practice, the cointegration results are not frequently used to predict macroeconomic variables, given that we differentiate each element of the factor representation individually.

Empirically, it is interesting to determine the number of common factors of the economy, given that we can summarize a large number of macroeconomic variables in few common trends. ${ }^{1}$ Furthermore, by estimating the common factors we can observe the orthogonal dynamics of the economy, which is very important for macroeconomic policy. These common factors, for example, may be related to specific groups of variables, and it is interesting to analyze mechanisms of transmission to other groups of variables. Additionally, we can estimate the confidence intervals for the loading weights, common factors, and common components, which allow us to carry out statistical inference in order to better understand economic phenomena.

The stochastic common trends represent the long-run behavior of the variables. Previous studies related to this paper are Duy and Thoma (1998), who evaluate the

\footnotetext{
${ }^{1}$ The common factors are equivalent to the common trends when we assume a static representation in the factor model. Barigozzi et al. (2016) develop the econometric theory for non-stationary DFMs with large datasets under different assumptions of the dynamic of the common factors.
} 
improvement of the cointegration relationship in VAR models; Eickmeier and Ziegler (2008), who examine the use of the factor-augmented vector autoregressive (FAVAR) in order to predict macroeconomic and financial variables, focusing on the US economy. They conclude that on average, factor forecasts are slightly better than other models. Banerjee et al. (2014) incorporate the error correction term in FAVAR models, showing that their approach generally offers higher forecasting accuracy relative to the FAVAR. Also, Eickmeier et al. (2014) prove different specifications of FAVAR models, using time-varying coefficients (tv) and stochastic volatility errors. The main conclusion is that the FAVAR models, regardless of the specification, outperform univariate models on in-sample forecasts. When they evaluate the outsample performance, there is no improvement with respect to the benchmark model. More recently, Hindrayanto et al. (2016) study the forecasting performance of a four factor model approach for large datasets. They conclude that a collapsed DFM is the most accurate model. Finally, Wilms and Croux (2016) propose a sparse cointegration method for a large set of variables by setting some coefficients in the cointegration relationship at exactly zero. They conclude that their method leads to significant forecast accuracy with respect to the method proposed by Johansen $(1988,1991)$. Other samples of reference are Stock and Watson (2002a, b), Marcellino et al. (2003), Peña and Poncela (2004), Reijer (2005), Schumacher (2007), Giannone et al. (2008), Eickmeier et al. (2014), Lahiri et al. (2015), and Panopoulou and Vrontos (2015), who show that DFMs are useful in order to reduce the forecast errors with respect to the traditional models, as autoregressive approaches and linear regressions with macroeconomic diffusion indexes. ${ }^{2}$ It is important to comment that, in a similar way as we have proposed in this study but in a stationary framework, Bräuning and Koopman (2014) propose to use collapsed dynamic factor analysis in order to predict target variables of the economy, exploiting the state-space representation between the target variables and the common factors. They conclude that the forecast accuracy is improved with respect to benchmark models.

However, most empirical applications have been carried out for the US or Euro economies. Therefore, we propose a FAVAR model to predict Mexican economic activity using concepts of cointegration such that we forecast $I(1)$ time series where the estimated common factors are the common trends of the economy. We readily exploit the long-run relationship between the common factors and the specific variable that we wish to predict. $^{3}$

We contribute to the literature in two ways: (1) empirically in determining the number of common trends of the Mexican economy and (2) the use of the common trends in order to predict economic activity. This is an advantage with respect to

\footnotetext{
${ }^{2}$ Certainly, macroeconomic diffusion indexes are related to DFMs. However, in this study we make a distinction between multivariate predictive approaches and the classic diffusion index forecasts given by Stock and Watson (2002b). Furthermore, we focus on a DFM from a static point of view. Once the common factors are estimated and their non-stationarity disentangled, we use the factors in the proposed FAVAR representation.

${ }^{3}$ A related study is Caruso (2015), who examines the flow of conjunctural data relevant to assess the state of Mexico's economy. Specifically, the author exploits the information embedded in macroeconomic news from both Mexico and the US, in a model constructed to nowcast Mexican real Gross Domestic Product (GDP) based on DFMs and Kalman filters.
} 
other alternatives, given that the FAVAR with cointegrated variables is very straightforward to implement computationally. Furthermore, we also direct our attention to the predictive capacity of macroeconomic variables and their common trends. In this way, we use the traditional method of principal components (PC) and additionally, partial least squares (PLS).

The rest of this paper is structured as follows. In Sect. 2, we summarize the historical behavior of the Mexican economy. In Sect. 3, we briefly explain the DFM and the FAVAR representation. In Sect. 4, we describe the estimation methods used. In Sect. 5, we describe the data, present the cointegration results, their descriptive predictive features, the empirical strategy to obtain small forecast errors, and the results obtained. Finally, we conclude in Sect. 6.

\section{The Mexican economy}

Mexico is one of the world's leading emerging countries. According to data from the International Monetary Fund (IMF), it is the 11th largest economy and the largest emerging country outside the BRICs, i.e., Brazil, Russia, India, and China (Rodriguez-Pose and Villarreal 2015). In 2015, Mexico's population ascended to 119.9 million and its GDP per capita stood at 9005.0 US dollars (World Bank 2016b).

After a prolonged period of sustained economic growth, the country began decelerating in the late 1970s. Following a sovereign default, Mexico encountered a severe economic crisis from 1982 to 1985. Subsequently, the Mexican government put forward a series of market reforms that culminated with the implementation of the North American Free Trade Agreement in 1994. These reforms included the privatization of previously government-operated firms, fiscal reforms, and opening the country to trade and foreign direct investment (FDI), among other actions (Kehoe and Ruhl 2010). Mexico's economic transformation was successful in reducing inflation, maintaining fiscal discipline, reducing its external debt burden, and increasing trade as a share of GDP (Hanson 2010). Nonetheless, this was not accompanied by high levels of economic growth, as between 1982 and 2015 the country's GDP grew at an average annual rate of 2.3\% (World Bank 2016a).

Moreover, in recent decades the Mexican economy has regressed on different fronts. In 1995, Mexico was responsible for $7.0 \%$ of trade among economies classified by the IMF as emerging and developing, behind China at $12.7 \%$. By 2008 , China's share was still the largest and totaled 22.3\%, while Mexico dropped to third at $5.4 \%$, behind Russia. Additionally, in 1995, China was the largest recipient of FDI to emerging and developing economies, accounting for $33.4 \%$, while Mexico was second, receiving $8.5 \%$. By 2008, Mexico's position had weakened considerably, falling to seventh at $3.2 \%$ (Kehoe and Ruhl 2010). Factors, such as rigidities in the labor market, an inefficient financial sector, and a lack of contract enforcement, have limited Mexico's capacity to benefit from its reforms and therefore hindered the country's economic growth (Kehoe and Ruhl 2010).

As an economy open to world markets, Mexico hosts many modern firms, notably in the automobile, aerospace, and foods and beverages sectors, which 
employ highly skilled, well-educated, and well-remunerated workers. Nonetheless, this represents only a small part of the economy and is concentrated in a few regions of the country. Another segment of the economy is characterized by high levels of informality, low-skilled work, low productivity levels, and out-of-date technologies. Unregistered firms in the informal sector employ close to half of Mexico's labor force, with workers that frequently lack access to a good education, reliable health care, and affordable financial services, conditions that strongly hamper their accumulation of human capital. Lastly, a third segment of the economy is made up of companies that, for long periods, have been protected from competition, particularly dominant firms in the energy and telecommunications sectors (Dougherty 2015).

During the global economic crisis of 2008-2009, Mexico's GDP suffered a significant contraction, which was accentuated by a reduction in the amount of remittances the country receives from migrant workers based in the US and the outbreak of influenza $\mathrm{A}(\mathrm{H} 1 \mathrm{~N} 1)$ throughout the country. Nevertheless, due to an upgraded macroeconomic policy framework and careful regulation of the financial system, Mexico did not suffer the type of financial and fiscal crises experienced in other countries (Schwellnus 2011).

In the years following the global economic crisis, the Mexican economy was characterized by a persistent trend of increasing debt-to-GDP, which grew from $29.0 \%$ in 2007 to $50.5 \%$ in 2016 , and a significant decline in the volume of oil production (World Bank 2016a). Output volatility in Mexico remained high, which can have high costs for individuals and for long-term growth. Furthermore, in Mexico, temporary disturbances in output are usually accompanied by temporary reductions in consumption, since a substantial share of the population is creditconstrained and the social safety net is generally weak. This is costly for individuals who prefer a smooth path of consumption and are averse to periods of unemployment or poverty (Schwellnus 2011).

Finally, during the last decade, Mexico has implemented a more ambitious and wide-ranging innovation policy aimed at getting closer to the technological frontier and generating higher levels of economic growth (Rodriguez-Pose and Villarreal 2015). By 2016, the expansion of economic activity was highly dependent on private consumption as low levels of investment and export demand were scarcely contributing to growth. In the medium term, economic and financial stability and an increase in external competitiveness, derived from the depreciation of the country's currency, are expected to boost private investment, exports, and hence economic growth (World Bank 2016b).

In this context, it is very important to formulate an econometric approach in order to successfully predict Mexican economic activity, which takes into account a large number of macroeconomic and financial variables associated with the behavior of the economy. Hence, we use a large non-stationary DFM in which the variables are summarized in the common trends of the Mexican economy. These common trends are used in a FAVAR representation, evaluating the out-sample forecast error one and two steps ahead during a recent phase of the economy. 


\section{The models}

In this section we introduce notation and describe the non-stationary DFM and the FAVAR model in order to use the common trends to predict a specific macroeconomic variable.

\subsection{Non-stationary dynamic factor model}

Suppose that $N$ large economic time series $Y_{t}=\left(y_{1 t}, \ldots, y_{N t}\right)^{\prime}$, observed from $t=1, \ldots, T$, are $I(1)$ and any two series $y_{i t}$ and $y_{j t}$ are cointegrated, such that the idiosyncratic component $\varepsilon_{t}=\left(\varepsilon_{1 t}, \ldots, \varepsilon_{N t}\right)^{\prime}$ is stationary. In this case, and following Stock and Watson (1988), there is a common factor representation as follows:

$$
Y_{t}=P F_{t}+\varepsilon_{t}
$$

where $P=\left(p_{1}^{\prime}, \ldots, p_{N}^{\prime}\right)^{\prime}$ is the $N \times r(r<N)$ matrix of factor loadings, where $p_{i}=$ $\left(p_{i 1}, \ldots, p_{i r}\right)$ and $F_{t}=\left(F_{1 t}, \ldots, F_{r t}\right)^{\prime}$ is the $r \times 1$ vector of common factors, or in this case, the common trends.

Given that any two series of $Y_{t}$ are cointegrated in the sense of Engle and Granger (1987), the dynamic of the common factors and the idiosyncratic components are the following:

$$
\begin{gathered}
F_{t}=F_{t-1}+\eta_{t} \\
\varepsilon_{t}=\Gamma(L) \varepsilon_{t-1}+a_{t}
\end{gathered}
$$

where the factor disturbances, $\eta_{t}=\left(\eta_{1 t}, \ldots, \eta_{r t}\right)^{\prime}$, are $r \times 1$ vectors, distributed independently from the idiosyncratic noises for all leads and lags. Furthermore, $\eta_{t}$ and $a_{t}$ are white noises with positive definite covariance matrices $\Sigma_{\eta}$ and $\Sigma_{a}$, respectively. Additionally, $\Gamma(L)$ collected the $N \times N$ matrices containing the autoregressive parameters of the idiosyncratic components where $L$ is the lag operator such that $L^{k} \varepsilon_{t}=\varepsilon_{t-k}$. These autoregressive matrices satisfy the usual stationarity assumptions.

The DFM in Eqs. (1)-(3) is not identified because for any $r \times r$ non-singular matrix $H$, the system can be expressed in terms of a new loading matrix and a new set of common factors as follows:

$$
\begin{gathered}
Y_{t}=P^{*} F_{t}^{*}+\varepsilon_{t} \\
F_{t}^{*}=F_{t-1}^{*}+\eta_{t}^{*},
\end{gathered}
$$

where $P^{*}=P H, F_{t}^{*}=H^{-1} F_{t}$, and $\eta_{t}^{*}=H^{-1} \eta_{t}$. The DFM in Eqs. (4) and (5) is observationally equivalent to that in Eqs. (1) and (2). A normalization is necessary to solve this identification problem and uniquely define the factors. In the context of PC factor extraction, it is common to impose the restriction $P^{\prime} P / N=I_{r}$ and $F^{\prime} F$ being diagonal, where $F=\left(F_{1}, \ldots, F_{T}\right)^{\prime}$ is a $T \times r$ matrix of common factors. Alternatively, we can set the restrictions $F^{\prime} F / T^{2}=I_{r}$ and $P^{\prime} P$ being diagonal; see Bai (2004) for identification issues in the non-stationary case. 
In Eqs. (1)-(3), if $\Gamma=0$ and $\Sigma_{a}$ is diagonal, then the DFM is known as strict; see Bai and $\mathrm{Ng}$ (2008). On the other hand, when $\Gamma \neq 0$ and $\Sigma_{a}$ is diagonal, there is serial correlation in the idiosyncratic noises and in this case the DFM is called exact; see Stock and Watson (2011). Chamberlain and Rothschild (1983) introduce the term approximate model when the idiosyncratic term does not need to have a diagonal covariance matrix. Forni et al. (2000) and Stock and Watson (2002a) generalize the approximate model, allowing for weak serial and cross-correlation. Furthermore, Bai and $\mathrm{Ng}$ (2002) and Bai (2003) also allow for heteroskedasticity in both the time and cross-sectional dimensions.

\subsection{The factor-augmented autoregressive model}

Once the non-stationary DFM is specified, we can use the common trends to predict a specific macroeconomic variable, denoted as $x_{t}$; see Stock and Watson (2005), Banerjee et al. (2013), among many others. It is important to comment that if forecasting is the objective, although $\left(x_{t}, F_{t}\right)^{\prime}$ are integrated or cointegrated, the FAVAR specification is quite convenient. Note that the optimal conditional expectation does not require stationarity or stability in the system. The theoretical justification is given by Lütkepohl (2006). More recently, Barigozzi et al. (2016) discuss several situations where a VAR estimated in levels is equivalent to a cointegrated VAR. Basically, when estimating a VAR in levels we can consistently estimate the parameters of a cointegrated VAR. Therefore, the FAVAR is provided as follows:

$$
\left(\begin{array}{c}
x_{t} \\
F_{t}
\end{array}\right)=\Phi(L)\left(\begin{array}{c}
x_{t-1} \\
F_{t-1}
\end{array}\right)+v_{t},
$$

where

$$
\Phi(L)=\left(\begin{array}{ccccc}
\Phi_{11}^{(k)} & \Phi_{12}^{(k)} & \Phi_{13}^{(k)} & \ldots & \Phi_{1 r+1}^{(k)} \\
0 & \Phi_{22}^{(k)} & 0 & \ldots & 0 \\
0 & 0 & \Phi_{33}^{(k)} & & 0 \\
\vdots & \vdots & & \ddots & \\
0 & 0 & 0 & & \Phi_{r+1 r+1}^{(k)}
\end{array}\right) L^{k+1}
$$

for $k=1, \ldots, p$, where $v_{t} \sim N\left(0, \Sigma_{v}\right)$. Intuitively, common economic trends that summarize its long-run behavior are used to predict a specific macroeconomic variable. For a similar representation but in the stationary context, see Bräuning and Koopman (2014). Note that expression (6) is the prediction equation; for example, assuming $p=1$, for any $h$ step ahead, then

$$
x_{t+h}=\Phi_{11} x_{t-(h+1)}+\Phi_{12} F_{1, t-(h+1)}+\cdots+\Phi_{1 r+1} F_{r+1, t-(h+1)}+v_{t+h} .
$$

Additionally, we can introduce deterministic components and seasonal and exogenous variables in Eq. (6). 


\section{Estimation}

The estimation of the parameters of Eq. (6) is obtained using restricted ordinary least squares (OLS). Furthermore, it is necessary to define the number of common factors and their factor estimates. In this section we describe some traditional methods to determine the number of non-stationary common factors. Additionally, we describe PC factor extraction and comment on an alternative method to estimate the common factors, known in literature as PLS.

\subsection{Determining the number of factors}

It was previously assumed that $r$ is known, however in practice it is frequently necessary to estimate it. In this subsection we describe two procedures to determine $r$ in the context of large DFMs, namely the Onatski (2010) procedure and the ratio of eigenvalues proposed by Ahn and Horenstein (2013). There are other alternatives to determine $r$, the Bai and $\mathrm{Ng}$ (2002) information criteria, the respective correction proposed by Alessi et al. (2010), and the procedure carried out by Kapetanios (2010), among many other approaches. Moreover, in the context of non-stationary DFMs, Ergemen and Rodriguez-Caballero (2016) use the procedure given by Hallin and Liska (2007) to determine the number of regional and global factors allowing fractional differencing in $Y_{t}$. However, and following Corona et al. (2017a), they show that the finite sample performance of the proposed procedures in this paper exhibits a good performance when we use data in first differences or levels and the common factors are $I(1){ }^{4}$

\subsubsection{Onatski (2010) procedure}

The Onatski (2010) procedure is based on the behavior of two adjacent eigenvalues of $\hat{\Sigma}_{Y}=T^{-1} Y^{\prime} Y$, for $j=1, \ldots, r_{\max }$. Intuitively, it is reasonable that when $N$ and $T$ tend to infinity, the difference between $\hat{\lambda}_{j}-\hat{\lambda}_{j+1}$ tends to zero while $\hat{\lambda}_{r}-\hat{\lambda}_{r+1}$ diverges to infinity, where $\hat{\lambda}_{i}$ is the $i$-largest eigenvalue of $\hat{\Sigma}_{Y}$. Onatski (2010) points out the necessity of determining a "sharp" threshold that separates convergent and divergent eigenvalues, denoted as $\delta$. The author gives the empirical procedure to determine the threshold and in practice, this approach is more robust in presence of non-stationarity and when the factors are weak or when the proportion of variance attributed to the idiosyncratic components is larger than the variance of the common component. We denote this estimator as $\hat{r}_{\mathrm{ED}}=\max \left\{j \leq r_{\max }: \hat{\lambda}_{j}-\hat{\lambda}_{j+1} \geq \delta\right\}$..

\subsubsection{The Ahn and Horenstein (2013) ratios of eigenvalues}

Ahn and Horenstein (2013) develop the consistency of the estimation of $r$ when they use the ratio of two adjacent eigenvalues of $\hat{\Sigma}_{Y}$ under the traditional assumptions of

\footnotetext{
${ }^{4}$ Alternatively, Bai (2004) proposes an information criteria for data in levels, modifying the $\operatorname{PC}(k)$ information criteria of Bai and $\mathrm{Ng}$ (2002) by multiplying the penalty function by $\alpha_{T}=T /[4 \log \log (T)]$.
} 
PC factor extraction. The two criteria provided by the authors are based on maximizing with respect to $j=1, \ldots, r_{\max }$ the following ratios:

$$
\begin{gathered}
\operatorname{ER}(j)=\frac{\hat{\lambda}_{j}}{\hat{\lambda}_{j+1}}, \\
\mathrm{GR}(j)=\frac{\ln \left(1+\hat{\lambda}_{j}^{*}\right)}{\ln \left(1+\hat{\lambda}_{j+1}^{*}\right)},
\end{gathered}
$$

where $\hat{\lambda}_{0}=\frac{1}{m} \sum_{i=1}^{m} \hat{\lambda}_{j} / \ln (m)$ and $\hat{\lambda}_{j}^{*}=\hat{\lambda}_{j} / \sum_{i=k+1}^{m} \hat{\lambda}_{i}$. The value of $\hat{\lambda}_{0}$ has been chosen following the definition of Ahn and Horenstein (2013), according to which $\hat{\lambda}_{0} \rightarrow 0$ and $m \hat{\lambda}_{0} \rightarrow \infty$ as $m \rightarrow \infty$.

\subsection{Principal components factor extraction}

The most popular method to extract static common factors is based on PC given that it does not require assumptions of the error distribution, and the estimation of the common component is consistent, among many other properties; see Bai (2003). This procedure separates the common component from the idiosyncratic noises by considering a cross-sectional averaging of the variables within $Y_{t}$ such that when $N$ and $T$ tend simultaneously to infinity, the weighted averages of the idiosyncratic noises converge to zero, with only the linear combinations of the factors remaining. Therefore, this method requires that the cumulative effects of the common component increase proportionally with $N$, while the eigenvalues associated with the idiosyncratic components remain bounded.

The PC estimator of $F_{t}$ can be derived as the solution to the following least squares problem:

$$
V_{r}(P, F)=\min _{F_{1}, \ldots, F_{T}, P}(N T)^{-1} \sum_{t=1}^{T}\left(Y_{t}-P F_{t}\right)^{\prime}\left(Y_{t}-P F_{t}\right)
$$

subject to the restrictions $F^{\prime} F / T^{2}=I_{r}$ and $P^{\prime} P$ being diagonal, where $F=$ $\left(F_{1}, \ldots, F_{T}\right)^{\prime}$ is a $r \times T$ matrix of common trends. The minimization problem in (10) is equivalent to maximizing $\operatorname{tr}\left[F^{\prime}\left(Y Y^{\prime}\right) F\right]$ where $Y=\left(Y_{1}, \ldots, Y_{T}\right)^{\prime}$ with the dimension $T \times N$. This maximization problem is solved by setting $\hat{F}$ equal to $T$ times the eigenvectors corresponding to the $r$ largest eigenvalues of the $T \times T$ matrix $Y Y^{\prime}$. The corresponding PC estimator of $P$ is given $b^{5}$ :

\footnotetext{
${ }^{5}$ Alternatively, if we choose the restrictions $P^{\prime} P / N=I_{r}$ and $F^{\prime} F$ being diagonal, the estimator of the matrix of factor loadings, $\hat{P}$, is $\sqrt{N}$ times the eigenvectors corresponding to the $r$ largest eigenvalues of the $N \times N$ matrix $Y^{\prime} Y$, with estimated factor matrix $\hat{F}=Y \hat{P} / N$. The difference is only computational, these latest restrictions are less costly when $T>N$, whereas $F^{\prime} F / T^{2}=I_{r}$ with $P^{\prime} P$ being diagonal are less costly when $T<N$.
} 


$$
\hat{P}=\frac{Y^{\prime} \hat{F}}{T^{2}} .
$$

Bai (2003) deduces that the rate of convergence and the limiting distributions of the estimated factors, factor loadings and common component is the stationary DFM when the cross-section and time dimensions tend towards infinity. Under the assumptions considered in this paper, Bai (2004) shows the consistency of $\hat{F}_{t}, \hat{P}$, and the common component. The finite sample performance of $\hat{F}_{t}$ is analyzed by Bai (2004) and recently by Corona et al. (2017b). The first author concludes that $\hat{F}_{t}$ is a close estimation of $F_{t}$ when the idiosyncratic errors are stationary and even if the sample size is moderately small (i.e., $N=100$ and $T=40$ ). The second authors consider structure dependence in the idiosyncratic errors and show that when the idiosyncratic errors are $I(0)$ we can obtain close estimations of $F_{t}$ even if $N$ is small and the variance of $\varepsilon_{t}$ is large. When the idiosyncratic errors are $I(1), \hat{F}_{t}$ works poorly. In this case, it is convenient to use the estimator given by Bai and $\mathrm{Ng}$ (2004). ${ }^{6}$ Other alternatives to estimate the common factors without differencing them are given by Barigozzi et al. (2016) and Corona et al. (2017b).

Note that the estimation of $F_{t}$ disregards the dynamic of Eqs. (2) and (3). The reason for this is that we estimate the common factors from static representation in the factor model. Corona et al. (2017b) incorporate the dynamic of Eq. (2) in a second step to obtain smooth estimates of the common factors using the Kalman filter. However, in this study we focus on a large DFM from static representation. For a technical discussion of the analogies and differences between static and dynamic representation, see for example Bai and $\mathrm{Ng}$ (2007). Thus, our approach is related to Bai (2004) and Bai and Ng (2004), who study non-stationarity in DFMs under a static representation.

\subsection{Partial least squares}

In addition to the estimation of $F_{t}$ by PC, we consider the PLS estimation, which takes into account the effect of a dependent variable. In a similar manner to Fuentes et al. (2015), we estimate the common factors in economic time series using PLS, denoted as $\tilde{F}_{t}$. Intuitively, the idea is to find the orthogonal latent variables that maximize the covariance between $Y$ and $x=\left(x_{1}, \ldots, x_{T}\right)^{\prime}$. The estimation process is iterative, and the first step consists in the eigenvalue decomposition of the following $T \times T$ matrix:

$$
M=Y x x^{\prime} Y^{\prime}
$$

Then, the first common factor, $\tilde{F}_{1 t}$, is the first eigenvector associated to the first eigenvalue of $M$. The second common factor is estimated from the residual matrix of $e=Y-B \tilde{F}_{1}^{\prime}$. To obtain the following common factors, the process is repeated $r-2$ steps using the $\tilde{F}_{1 t}, \ldots, \tilde{F}_{r-1 t}$ common factors in each step.

\footnotetext{
${ }^{6}$ According to Bai and $\mathrm{Ng}$ (2004), if $\varepsilon_{t}$ is not stationary, it is necessary to differentiate $Y_{t}$ to consistently estimate $F_{t}$ using $\hat{F}_{t}=\sum_{s=1}^{t} \hat{f}_{s}$ where $\hat{f}_{t}$ is the PC factor estimated when using data in first differences.
} 


\section{Empirical analysis}

In this section we present the data from the Mexican economy used in this study, describe the methodology to evaluate the accuracy of the common trends in order to predict the Mexican economy, determine the number of common trends, and analyze their dynamic by evaluating the performance of the FAVAR model proposed in Sect. 2 with respect to benchmark models.

\subsection{Data}

Initially, we consider 511 macroeconomic and financial variables obtained from the Banco de Información Económica (BIE) of the Insituto Nacional de Geografía y Estadística (INEGI), Mexico's national statistical agency. The analysis covers from March 2005 to April 2016, hence, $T=133$. The blocks of variables are considered according to the INEGI division, and additionally, we compare this division with respect to the National Institute's Global Econometric Model, which considers nine blocks with a total of 67 variables. $^{7}$

According to our approach, it is necessary that all variables are integrated of order one, so that, if factors are found, these are the common trends of the observations. In this case, we consider only $I(1)$ variables according to the Augmented Dickey-Fuller (ADF) test. ${ }^{8}$ When needed, the time series have been deseasonalized and corrected by outliers using X-13ARIMA-SEATS developed by the US Census Bureau. ${ }^{9}$ Following Stock and Watson (2005), outliers are substituted by the median of the five previous observations.

Finally, according to these non-stationary conditions, we work with the following database of $N=211$ variables (number between parentheses) ${ }^{10}$ :

- Balance of trade (19)

- Consumer confidence (18)

- Consumption (9)

- Economic activity (13)

- Employment (5)

- Financial (35)

- Industrial (58)

- International (17)

- Investment (8)

- Miscellaneous (18)

- Prices (11). ${ }^{11}$

\footnotetext{
7 https://nimodel.niesr.ac.uk.

${ }^{8}$ See Barigozzi et al. (2016) for a similar approach.

${ }^{9}$ https://cran.r-project.org/web/packages/seasonal.pdf.

${ }^{10}$ See Annex with the description of each block of variables included.

${ }^{11}$ It is well known that the prices can be $I(2)$. In our sample period seven prices are $I(2)$ and they are differenced.
} 
Furthermore, we define $x_{t}$ as the Global Index of Economic Activity (IGAE, Indicador Global de la Actividad Económica). ${ }^{12}$

\subsection{Estimating the common trends}

We apply the criteria described in this article to detect the number of factors. We use an $r_{\max }=11$. The results indicate that $\hat{r}_{\mathrm{ER}}=\hat{r}_{\mathrm{GR}}=2$ and $\hat{r}_{\mathrm{ED}}=5 .{ }^{13}$ Given that Onatski (2010) is more robust in the presence of non-stationarity, see Corona et al. (2017a), we work with this number of factors. ${ }^{14}$

Figure 1 plots the results of the ratios and differences of eigenvalues with the respective threshold. Note that, intuitively, it is congruent that the ratio of eigenvalues of Ahn and Horenstein (2013) determines one and two common factors, given that the first and second differences of eigenvalues are large, while the others are practically zero. However, the estimation of the "sharp" threshold is one of the main contributions from Onatski (2010), which as we have mentioned, consistently separates convergent and divergent eigenvalues. Furthermore, the five common factors explain $79.19 \%$ of the total variability. Specifically, the first common factor explains $46.14 \%$, the second $19.59 \%$, the third $6.2 \%$, the fourth $4.75 \%$, and the fifth $2.51 \%$.

Figure 2 plots the behaviors between $\ln x_{t}$ (deseasonalized) and each common factor extracted by PC and PLS. We observe that the first common factor, for each procedure, is similar to $\ln x_{t}$ with contemporaneous linear correlations of 0.95 for PC and 0.96 for PLS. The second common factors are slightly correlated with $\ln x_{t}$, having contemporaneous correlations of 0.13 and 0.08 for PC and PLS, respectively. On the other hand, $\tilde{F}_{3 t}$ and $\tilde{F}_{5 t}$ have an inverse behavior, although the correlations with respect to $\ln x_{t}$ are around -0.01 . In the other cases, the estimated common factors are positively related to $\ln x_{t}$ but the linear correlations are drastically small. These facts indicate that contemporaneously, only the first two common factors are associated with economic activity. It is interesting to mention that these two factors explain $65.73 \%$ of the total variability. Note that it is complicated to establish the predictive capacity between the common factors, and it is necessary to evaluate it in the FAVAR model. Furthermore, it is clear that the sample period includes the economic crisis of 2008-2009; however, Stock and Watson (2011) show that the PC estimator of the factors is consistent even with certain types of breaks or time variation in the factor loadings.

Figure 3 shows the weighted average contribution of each variable block in the common factors estimated by PC. Each color bar represents the contribution of the percentage of explanation of each variable group with respect to each common factor, denoted as follows:

\footnotetext{
${ }_{12}$ Note that the block of economic activity includes the components of the aggregate IGAE. Hence, this specific variable is not included in the block.

13 Additionally, we estimate the Bai and $\mathrm{Ng}$ (2002) information criteria using data in levels and firstdifferenced data. In both cases, the three criteria tend to $\hat{r}=r_{\max }$.

${ }^{14}$ For the US economy, Alessi et al. (2010) determine six common factors using the database from Stock and Watson (2005).
} 

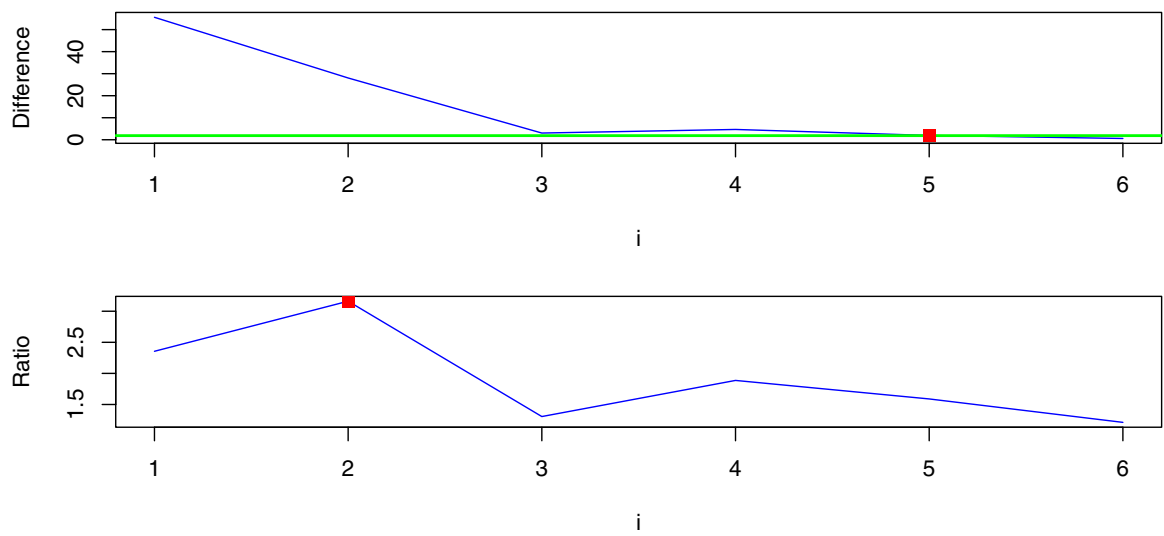

Fig. 1 Determination of the number of factors through the Onatski (2010) procedure, $\hat{\lambda}_{i}-\hat{\lambda}_{i+1}$ (top panel) and ratio of eigenvalues (bottom panel), $\hat{\lambda}_{i+1} / \hat{\lambda}_{i}$, for $i=1, \ldots, 6$

$$
\hat{\mu}_{j g}=\sum_{i_{g}=1}^{N_{g}}\left|\hat{p}_{i_{g} g}\right| / N_{g} \quad \text { for } j=1, \ldots r, \text { and } g=1, \ldots, G,
$$

where $\hat{p}_{i_{g} j g}$ is the loading weight of each group of variables; $G$ is the number of blocks of variables; and $N_{g}$ is the number of variables in each group. Specifically, the order of the groups of variables is computed as $r^{-1} \sum_{j=1}^{r} \hat{\lambda}_{j} \hat{\mu}_{j g}$ where $\hat{\lambda}_{j}$ is the variance contribution of each common factor. The block that most explains the common factors is the miscellaneous group, economic activity, and balance of trade blocks. On the other hand, prices, employment, and consumer confidence are the least relevant groups of variables. Note that this importance is in terms of the loading contribution and it is not interpreted as predictive power. Specifically, the first common factor is more correlated with the IGAE of tertiary activities (0.99), the second common factor with the economic situation with respect to last year (0.94), the third common factor with oil exports (0.78), the fourth common factor with edification (0.70), and the fifth common factor with the food industry (0.53).

In order to evaluate if the common factors are the common trends of $x_{t}$, we carry out the cointegration exercise. The possible cointegration relationship is given by:

$$
\begin{aligned}
\hat{v}_{t}= & \ln x_{t}-\underset{(0.0000)}{4.6369}-\underset{(0.0000)}{0.0719} \hat{F}_{1 t}-\underset{(0.0000)}{0.0098} \hat{F}_{2 t} \\
& -\underset{(0.0000)}{0.0003 \hat{F}_{3 t}}+\underset{(0.0000)}{0.0008} \hat{F}_{4 t}+\underset{(0.0000)}{0.0002} \hat{F}_{5 t} .
\end{aligned}
$$

We estimate the ADF test with its respective $p$ value (in parentheses), obtaining the following results:

$$
\text { ADF test: }-3.4382(0.01)
$$

Then, we can verify that the common trends of a large dataset of the economic variables are cointegrated with economic activity. Furthermore and following Bai 

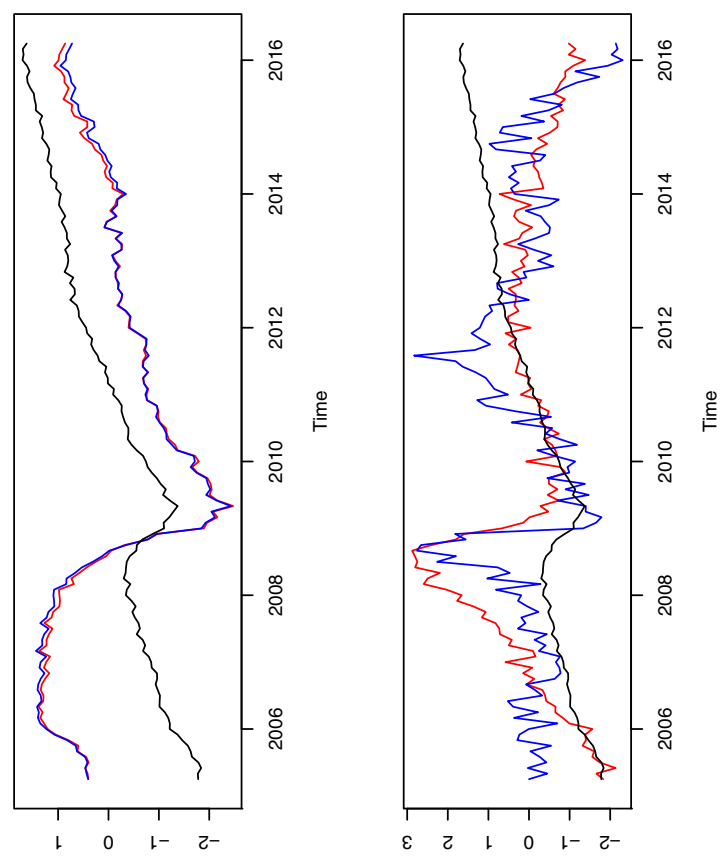

$\stackrel{2}{2}$

$\stackrel{0}{E}$

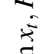

$\Phi$

气

氠

옹

무

$\widehat{\text { 年 }}$

$\stackrel{5}{\Xi}$

$\bar{\Xi}$

ลี

를

$\frac{0}{\overline{7}}$

$\stackrel{2}{\Xi}$

商

‡
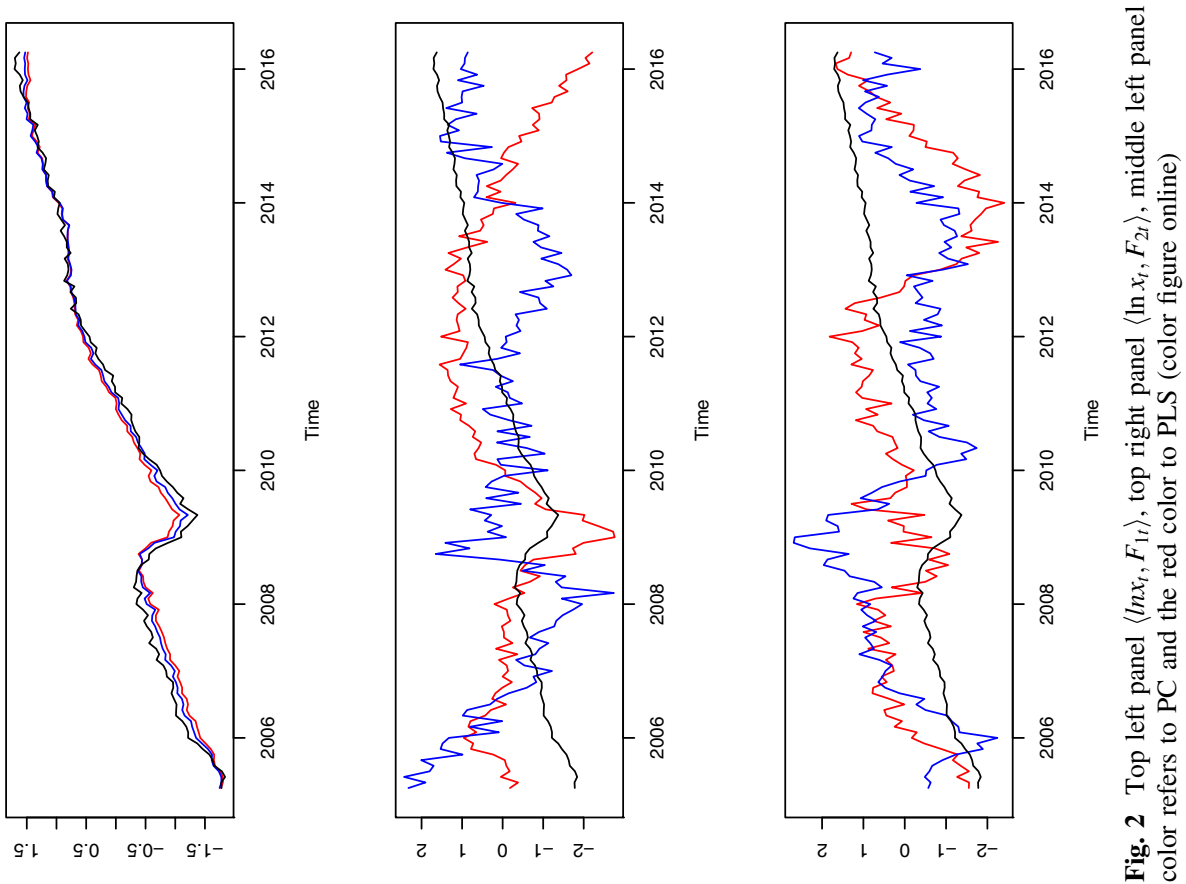


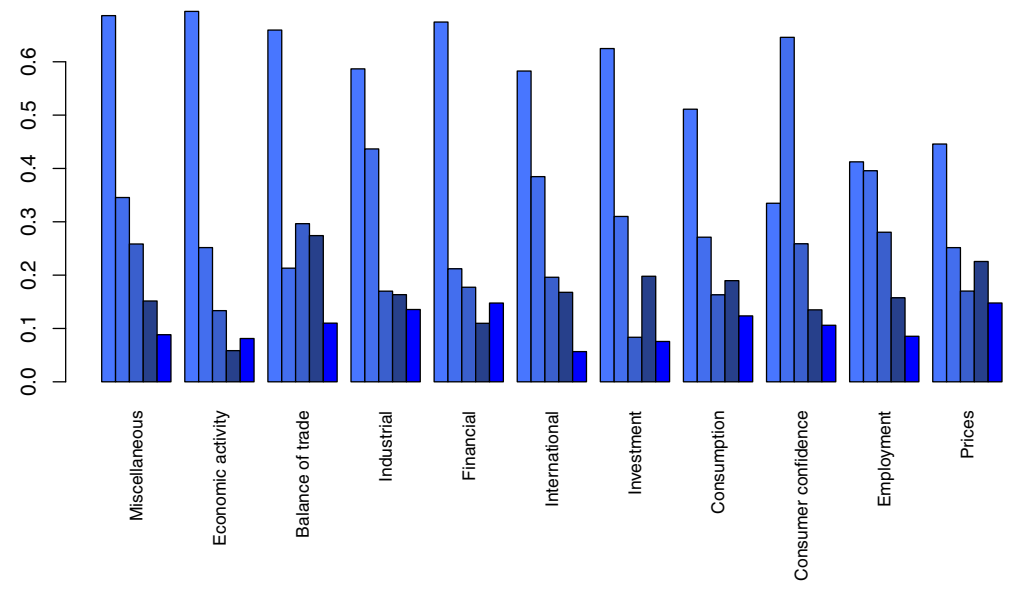

Fig. 3 Weighted mean $\hat{\mu}_{j g}=\sum_{i_{g}=1}^{G}\left|\hat{p}_{i_{g} g}\right| / N_{g}$ for $j=1, \ldots, r$, and $g=1, \ldots, G$, where $G$ is the number of blocks of variables and $N_{g}$ is the number of variables in each group

and $\mathrm{Ng}$ (2004), first, we carry out a Panel Analysis of Non-stationarity in Idiosyncratic and Common Components (PANIC) on the idiosyncratic errors obtained using the "differencing and recumulating" method in order to disentangle the non-stationarity in this component. Second, we apply a PANIC to the idiosyncratic components estimated using data in levels as we have proposed in this study. In the first analysis, we obtain a $p$ value of 0.1171 while in the second, we obtain a $p$ value of 0.0000 . Although in the first case $\hat{\varepsilon}_{t}$ is statistically non-stationary, the $p$ value is around the uncertainty zone. Furthermore, we apply the variant of the ADF test proposed by Bai (2004) with the aim of detecting how many of the five common factors are non-stationary. As we expected, the tests show that the five common factors are non-stationary. Therefore, we conclude that the idiosyncratic terms are stationary and the common factors are non-stationary; hence, we can also argue that the elements of $Y_{t}$ are cointegrated and the common factors are the common trends of $Y_{t}$ and $x_{t}$.

Note that Eq. (13) is the static version of Eq. (7). The goal of this exercise is to determine whether $F_{t}$ are the common trends of $x_{t}$ and $Y_{t}$. We use this information to forecast the target variable with the FAVAR model presented in Sect. 2.

\subsection{Evaluating the use of common trends to predict Mexican economic activity}

It is important to have an empirical strategy to adequately predict the target variable. Consequently, with the aim of selecting the forecast model, we consider all possibilities of FAVAR models, $\sum_{i=1}^{r}{ }^{r} C_{i} \times 396$, where ${ }^{r} C_{i}$ is the binomial coefficient $\left(\begin{array}{l}r \\ i\end{array}\right)$ and 396 is obtained as the product of 11 seasonal dummies (3-12 and none), 3 deterministic specifications in the FAVAR model (none, constant and trend), and 12 lags (1-12). Therefore, the lag order, the seasonal dummies, the 
deterministic component, and the factors are directly determined by minimum outsample forecast error. The training sample covers from March 2015 to April 2016, such that we forecast 12 periods ( 1 year) for $h=2$. This forecast period is one of relative economic and political stability in Mexico. For example, during this time frame, the annual growth rate of Mexico's GDP in any quarter was never lower than $2.3 \%$ and never higher than $2.8 \%$ (INEGI 2016). Moreover, the country's economic performance tends to be more volatile in times close to presidential elections in Mexico, and to a lesser degree in the US, which do not coincide with our forecast period. Statistically, this period represents around $10 \%$ of the number of observations and discounting the degrees of freedom, we are able to represent $25 \%$ of $T-K$ where $K$ is the number of parameters in the FAVAR model.

For each model, we compute the forecast error. The forecasts are dynamic, so that we update $T+1$ in each month. We selected the model that minimizes the Root Mean Square Error (RMSE). ${ }^{15}$ Furthermore, we focus on the models that give a forecast error lower than a threshold. This threshold is determined directly using Eickmeier et al. (2014) as a reference. In their work they predict several macroeconomic variables using FAVAR models, FAVAR-tv, FAVAR-tv with stochastic volatility errors and univariate models. For one and two step ahead, forecasting the US GDP, the RMSE values in in-sample forecasts are 0.76 and 0.80 considering all periods for $h=1$ and $h=2$, respectively. However, we select a threshold of 0.5 to obtain more accurate forecasts. Note that, if we predict $\Delta \ln x_{t}$ for the first step ahead, the forecast error is $e_{T+1}=\left(\ln x_{T+1}-\ln x_{T}\right)-$ $\left(\ln x_{T+1}^{f}-\ln x_{T}\right)=\ln x_{T+1}-\ln x_{T+1}^{f}$, i.e., it is equivalent to forecasting the level of the first step ahead. Therefore, we focus on the levels of the IGAE.

\subsection{Using common trends to predict Mexican economic activity}

First, in order to descriptively evaluate the predictive capacity of each variable, we calculate the cross-correlation between $y_{i t-h}$ and $x_{t}$ and consequently:

$$
\rho_{h}^{*}=\operatorname{corr}\left(y_{i t-h}, x_{t}\right) \mid\left\{\max \left(h \leq 12: \operatorname{Prob}\left(\operatorname{corr}\left(y_{i t-h}, x_{t}\right)\right)<\alpha\right)\right\},
$$

where $\alpha=0.05$. Figure 4 plots the results of the previous equation. Note that the top panel plots the $\rho_{h}^{*}$ with the confidence interval. The middle panel shows their corresponding maximum significant lag, $\max \left(h \leq 12: \operatorname{Prob}\left(\operatorname{corr}\left(y_{i t-h}, x_{t}\right)\right)<\alpha\right)$ and bottom panel presents the mean absolute correlations for each block of variables. Note that the block of variables most highly correlated with the future of $x_{t}$ is the miscellaneous one. It is interesting to note that all significant variables of this block are positively correlated with the IGAE. Other interesting variable blocks are the economic activity and financial groups. On the other hand, the blocks least correlated with the future of $x_{t}$ are consumer confidence, employment, and prices.

\footnotetext{
15 As we have mentioned in the introduction, the goal of this paper is to forecast Mexican economic activity. To this end, we have two measures: quarterly, GDP; and monthly, IGAE. In an early analysis, we prove that IGAE is perfectly correlated with GDP. In this case, given the monthly frequency data, it is more convenient to forecast the IGAE, with $x_{t}$ as the target variable.
} 

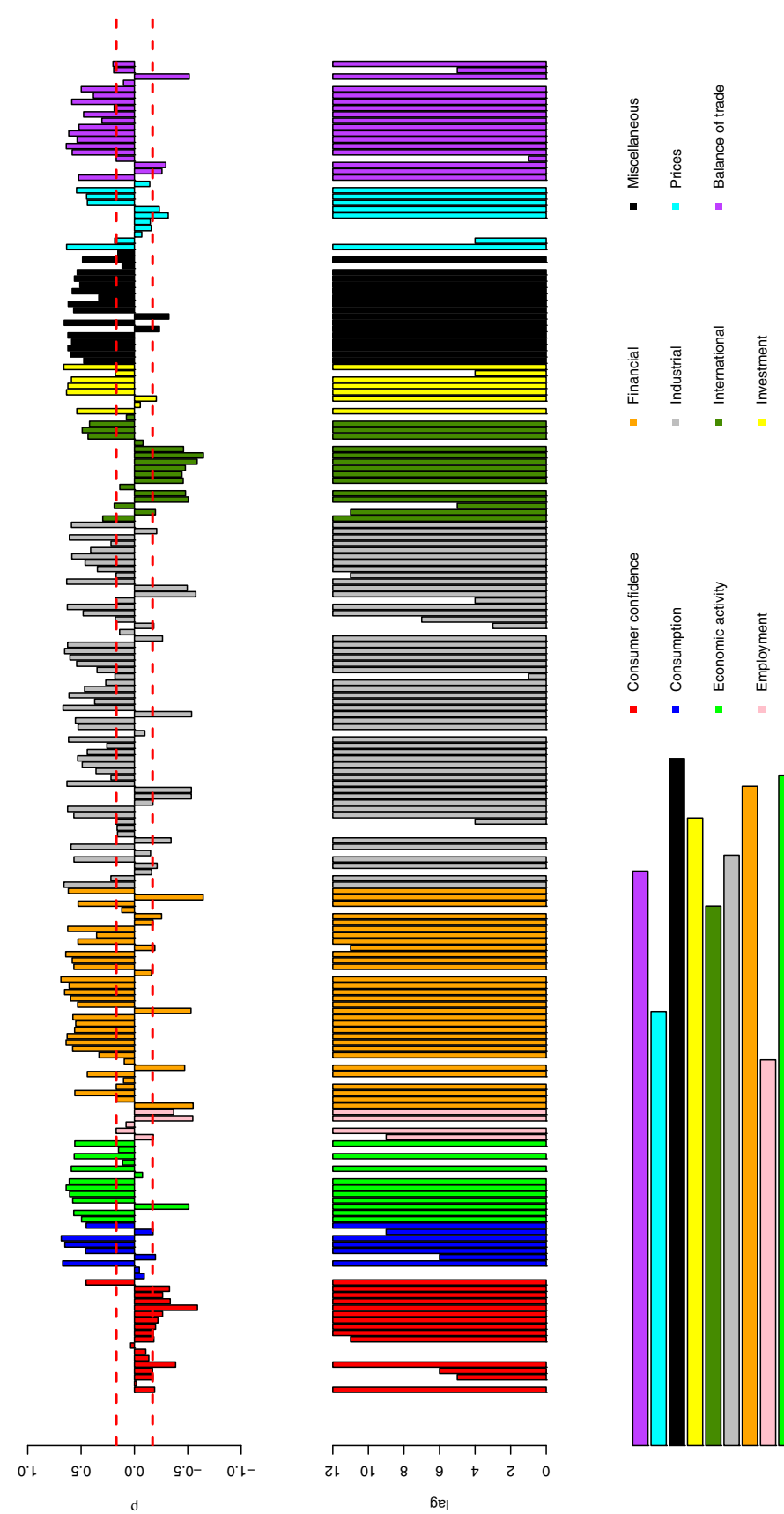

$-\infty$

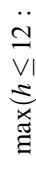

$\stackrel{\circ}{-}$

iิ

苛

苯

:

帘

:

象

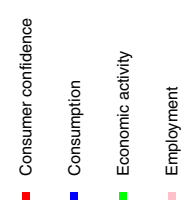

$\stackrel{0}{\circ}$

क 过

$\overline{0}$

踏

- $\frac{0}{7} \frac{0}{0}$

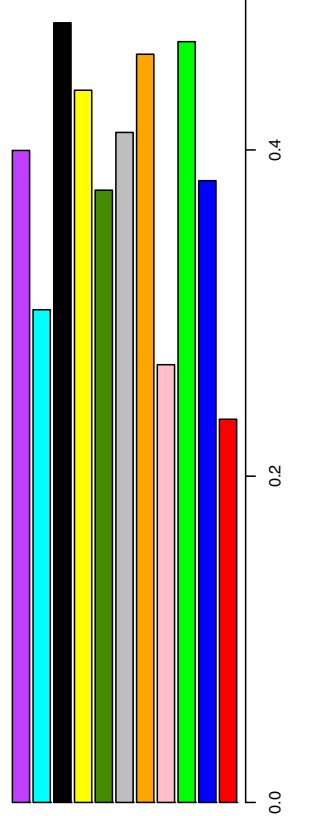

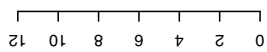

6 ㅌ

- 웅 
It is important to state that the PANIC carried out on the idiosyncratic errors and common factors shows that the elements of $Y_{t}$ are cointegrated; hence, it is reasonable to expect that the correlations between $y_{i t}$ and $x_{t}$ are not spurious.

Once the models are estimated, we review the forecast errors lower than the threshold in the training sample. Figure 5 plots the historical behavior of the RMSE for the selected predictive models. The top panel plots the RMSE for $h=1$. Note that the PC gives slightly more accurate results than PLS. Furthermore, the dispersion of the RMSE for PLS is larger than PLS and neither approach presents outliers. The bottom panel shows the results for $h=2$. We can see that for both procedures, the forecast errors are slightly increased with respect to $h=1$. It is interesting to mention that for both $h$ the tails from both procedures are intercepted. This graph is important because this behavior is expected for the following two predicted months.

Using the models from Fig. 5 we predict two steps ahead: May and June 2016. Note that we have $n$ models, such that it is necessary to combine the forecasts. Thus we propose a weighted average, obtaining loadings similar to the PLS procedure by solving the following optimization problem:

$$
\rho_{1}=\underset{w, b}{\max \operatorname{cor}}\left(X^{f} w, x b\right) \quad \text { subject to } \quad \operatorname{Var}\left(X^{f} w\right)=\operatorname{Var}(x b)=1,
$$

where $w=\left(w_{1}, \ldots, w_{n}\right)$. In order to normalize the loading weights, we carry out the following scaling: $w^{*}=n\left(\sum_{i=1}^{n} w_{i}\right)^{-1} w$, such that the loading weights are between 0 and 1 . Figure 6 shows the forecast density, the predictions, and the observed data. We plot the confidence interval to $95 \%$. Note that for $h=1$, PLS is more accurate than PC, while for $h=2$, PLS is less accurate. The models are centered on the mean of the distribution. Moreover, the forecast density acquires the observed data. Furthermore, focusing on $h=2$, the distribution of PC has two modes and the predicted data tend towards the center of the distribution. On the other hand, for PLS, it tends towards the median of the distribution.

An interesting question is: which common trends are helpful to reduce forecast error? To this end, we compute the following coefficients through OLS:

$$
\partial e_{t} \mid D_{t i}=1<0 \quad \text { and } \operatorname{Prob}\left(\partial e_{t} \mid D_{t i}=1\right)<0.10 \quad \text { for } i=1, \ldots, N_{\mathrm{m}},
$$

where $N_{\mathrm{m}}$ is the number of models for each procedure. In other words, we carry out a linear regression between the forecast errors according to each procedure and dummy variables that specify the combination of common trends $F_{1 t}, F_{2 t}, F_{3 t}, F_{4 t}$, and $F_{5 t}$ for both procedures. Figure 7 plots the result for each procedure in each $h$. We can see that, in PC, $F_{1 t}$ is a very important common factor to reduce the forecast error for $h=1$, whereas $F_{1 t}, F_{2 t}, F_{4 t}$, and $F_{5 t}$ are important for $h=2$. Furthermore, in the PLS approach $F_{1 t}, F_{2 t}, F_{4 t}$, and $F_{5 t}$ are relevant common factors for $h=1$ whereas $F_{1 t}$, and $F_{2 t}$ are for $h=2$. In fact, for both procedures the interaction of all common factors is important to reduce the forecast errors. This result completes the conclusions when we analyze Figs. 1 and 4, where all common factors are helpful to reduce the forecast errors.

In order to evaluate the forecast accuracy in "real time," we predict two steps ahead (May and June 2016). Figure 8 shows the forecast accuracy of the following models: 

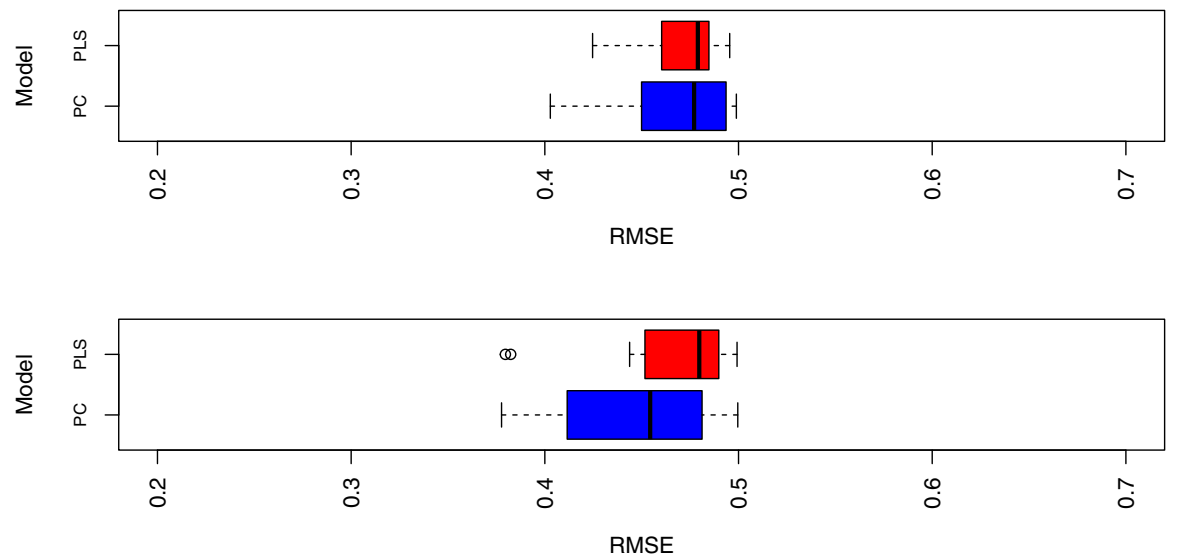

Fig. 5 Box plots for the RMSE of out-sample forecasts for the selected models. The top panel is $h=1$ and the bottom panel $h=2$. The blue color refers to PC and the red color to PLS (color figure online)
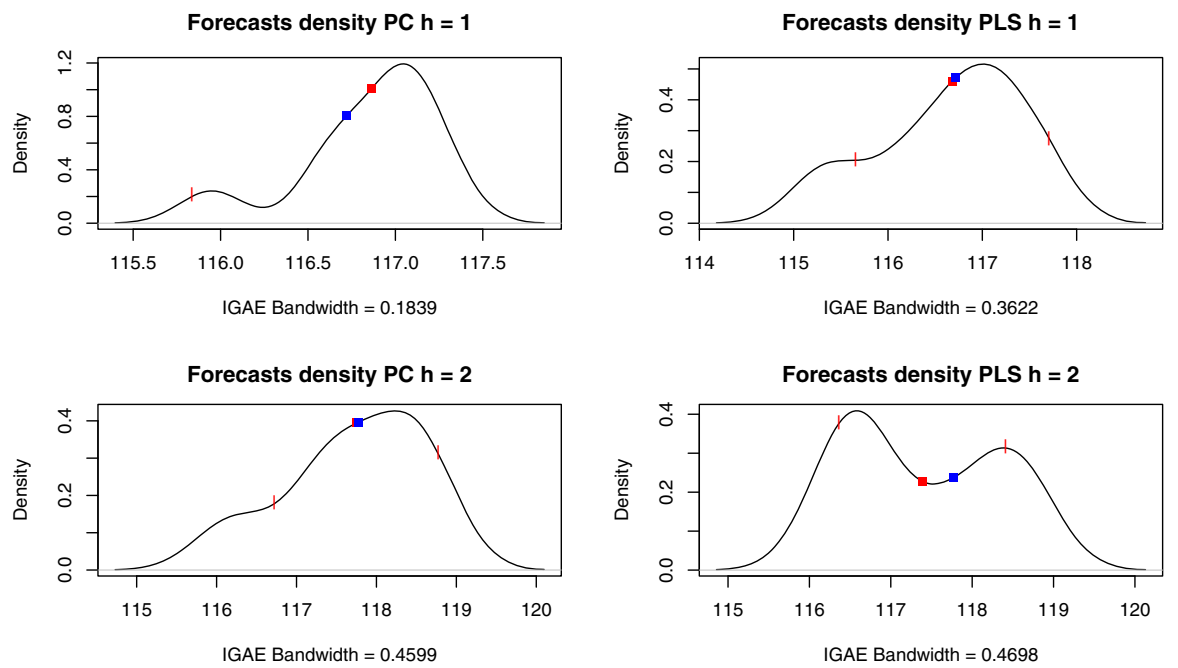

Fig. 6 Forecast densities, forecast points (red color), and observed data (blue color) (color figure online)

(i) PC, (ii) PC using only factors that contribute to reducing the forecast error denoted as PC (2), (iii) PLS, (iv) PLS (2), (v) the average between the first and third models, and (vi) the average between the second and fourth models. We can see that for $h=1$ PLS, PLS (2) and the forecast average of PC and PLS are the most accurate model with 0 forecast error for May 2016. For $h=1$, PC gives a forecast error of 0.1 in June 2016. In conclusion, and with reference to Fig. 5, the results are as expected given that PC and PLS give forecast errors lower than the selected threshold.

It is interesting to mention the historical behavior of the models. Hence, we first analyze the RMSE of the benchmark models: the Autoregressive Integrated Moving Average (ARIMA) and the macroeconomic diffusion index (Stock and Watson 2002b). Figure 9 plots the results for the out-sample training. For $h=1$, we observe 
$\operatorname{Pch}=1$

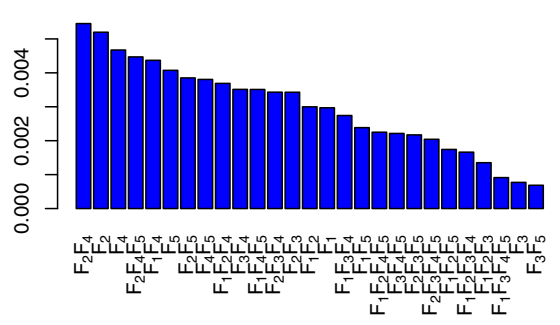

$\operatorname{Pch}=2$

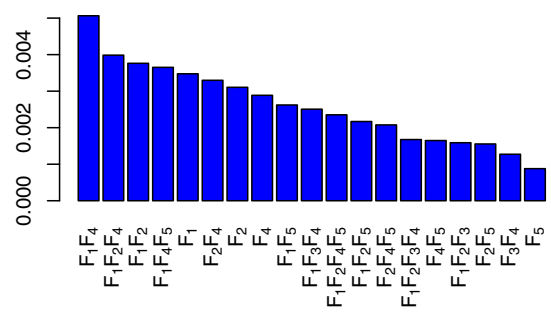

PLS h = 1

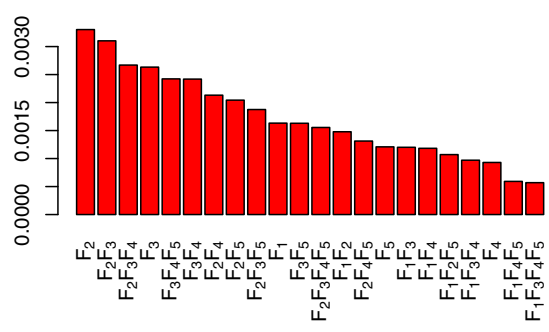

PLS h = 2

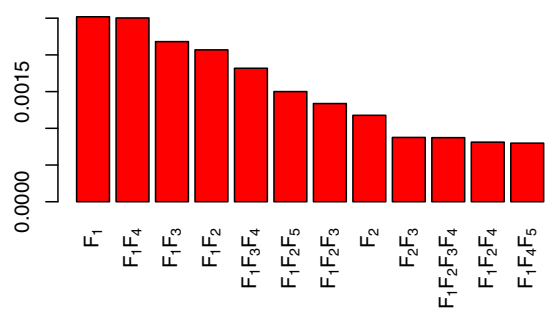

Fig. 7 Effects of variables on forecast errors: $\partial e_{t} \mid D_{t i}=1<0$ and $\operatorname{Prob}\left(\partial e_{t} \mid D_{t i}=1\right)<0.10$. The blue color refers to PC and the red color to PLS (color figure online)

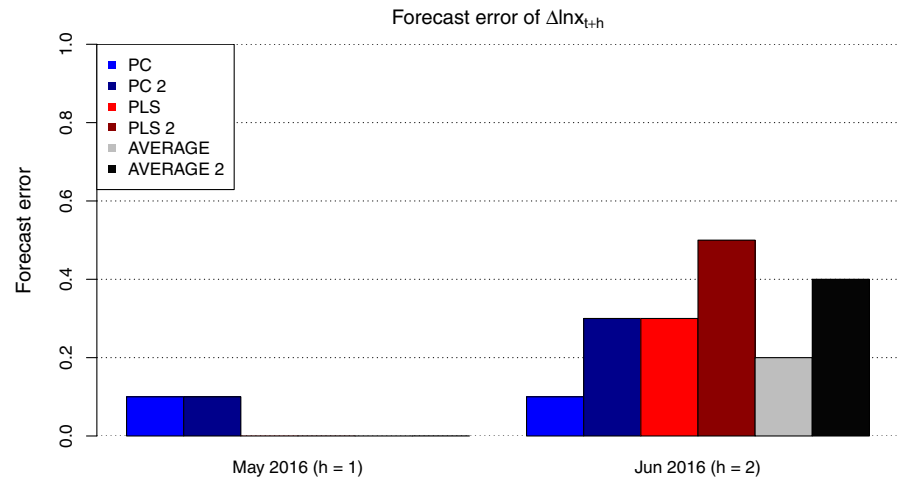

Fig. 8 Observed forecast error for May $2016(h=1)$ and June $2016(h=2)$. PC (blue color), PC 2 (deep blue color), PLS (red color), PC 2 (deep red color), average of forecasts (gray color), and average 2 of forecasts (black color). The number 2 indicates that the models only considered the variables that satisfy $\partial e_{t} \mid D_{t i}=1<0$ and $\operatorname{Prob}\left(\partial e_{t} \mid D_{t i}=1\right)<0.10$ (color figure online)

that the RMSE interval is between 0.82 and 1.07 for the ARIMA model, while for the macroeconomic diffusion index it is between 0.62 and 0.83 . For $h=2$ the errors are slightly reduced in both cases; however, the macroeconomic diffusion index has better results. Hence, note that the inclusion of the factor in linear models reduces the forecast error. Then, we would expect the FAVAR models to show a small RMSE. ${ }^{16}$

\footnotetext{
${ }^{16}$ Alternatively, we can consider RMSE in terms of benchmark models like several authors. However, we decide to use the RMSE to easily verify whether the FAVAR models give RMSEs lower than the selected threshold of 0.5 .
} 

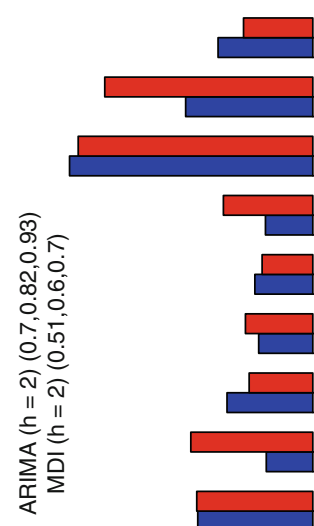

9) $d d \forall$

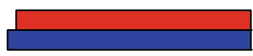

๙ิำ

م.

ก

ลิ

ᄃ

$\sum_{\frac{1}{\alpha}}^{\frac{1}{2}}$
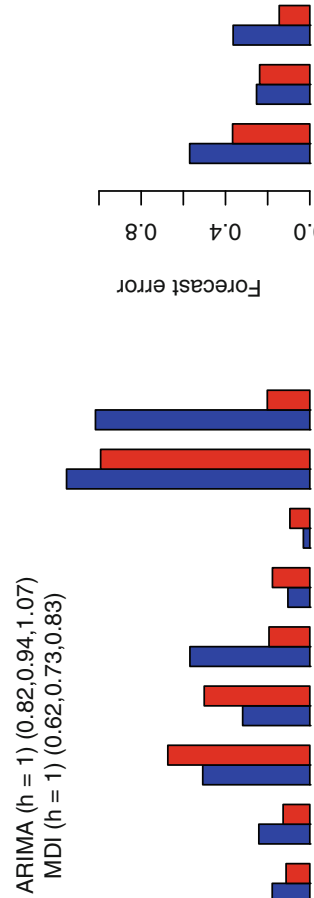

91 dew

$9+9 \ominus$

9t uer

$\widehat{D}_{\widehat{\infty}}$

के

กิ

@อ

II $\widehat{F}$

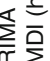

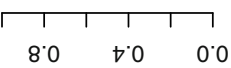

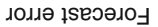

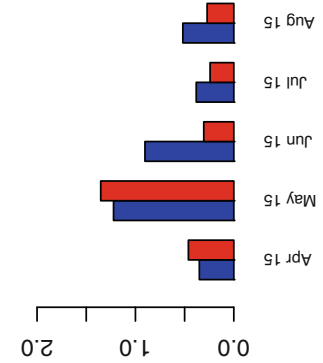

גАر

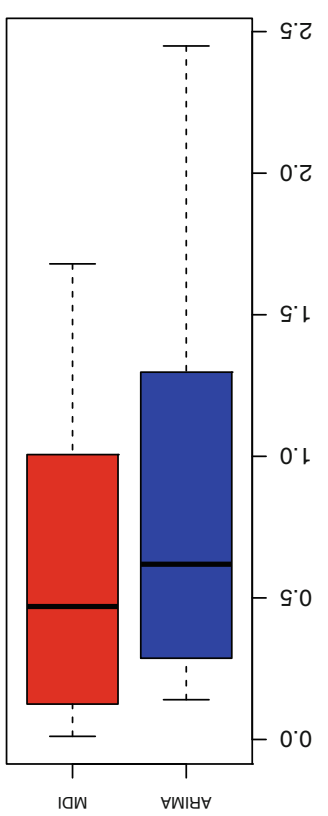

əəроW

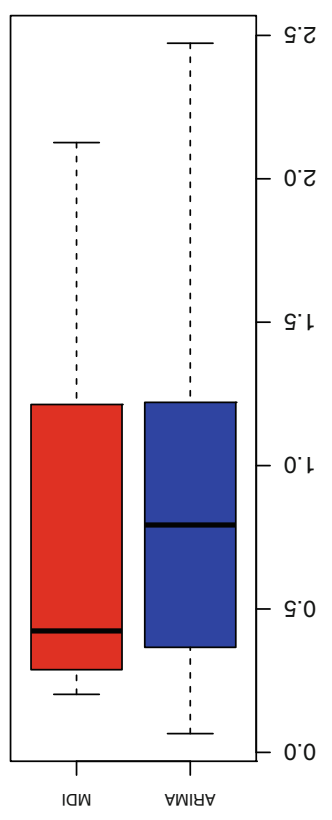

ןәроw

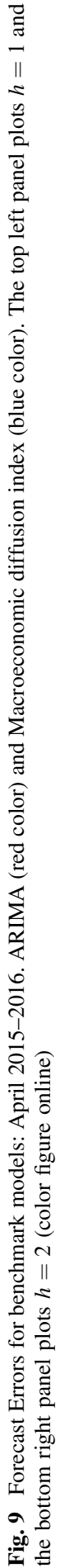


Figure 10 plots step-by-step the forecast errors of the FAVAR models considering the approach presented in this work. Note that the RMSE interval of PC for $h=1$ is between 0.27 and 0.67 and for $h=2$ between 0.29 and 0.59 . The RMSE mean values are 0.47 and 0.44 for each $h$, respectively. Note that in both $h$, February 2016 is the outlier forecast error. On the other hand, for PLS and $h=1$, the forecast errors are between 0.34 and 0.60 and for $h=2$, the confidence interval is between 0.3 and 0.64. In this case, the mean of RMSE is 0.47 for each $h$, respectively. Note that the improvement with respect to the ARIMA model and macroeconomic diffusion index is relevant, above all when the factors are estimated using PC. Note that the forecast errors are very similar between PC and PLS.

A question of interest is: are the models consistent through the training sample? We can obtain different models in each step ahead, in which case the consistency of the predictors may be questionable. Taking into account only the selected models, we can observe in Fig. 11 that all models are robust in $h=1$. In fact, $76 \%$ of the models are within the threshold and for $h=2$, the behavior of the predictions is similar to May 2016. Note that the predictions for May and June 2016 are carried out with information up to April 2016. Hence, we present the forecast in $h=1$ for May 2016 and $h=2$ for June 2016. The model is not updated as in the previous forecasts. It is interesting to note that February 2016 was the most complicated month to predict; however, the robustness of the selected models is reasonable. The reason why February 2016 was a complicated month to predict can be explained by the fact that this month has 29 days, and the seasonal variables and the dynamics between the variables do not account for this effect.

\section{Conclusions and further research}

In this paper we estimated the common trends of the Mexican economy using a large dataset of macroeconomic variables. Using cointegration concepts, we estimated the common trends using $I(1)$ variables through PC, determining the number of common factors according to the Onatski (2010) and the Ahn and Horenstein (2013) procedures. Alternatively, we estimated the common factors using PLS.

We find that 211 macroeconomic and financial variables can be summarized in at most $\hat{r}=5$ common trends, which are cointegrated with Mexican economic activity. Furthermore, we use the common trends in a FAVAR model with the aim of predicting Mexican economic activity. We statistically evaluate the predictive capacity of the common trends, where we can see that each common factor reduces the forecast error. Additionally, we observe that the forecast error is reduced with respect to the ARIMA and factor-augmented regressions, such that the common trends are useful to predict Mexican economic activity.

An important conclusion is that the macroeconomic common trends can be used in more sophisticated models in order to reduce the forecast errors. Additionally, note that in this study we used data in levels in order to estimate the common factors. This is empirical evidence on the use of DFMs when we do not transform the data to stationarity. 


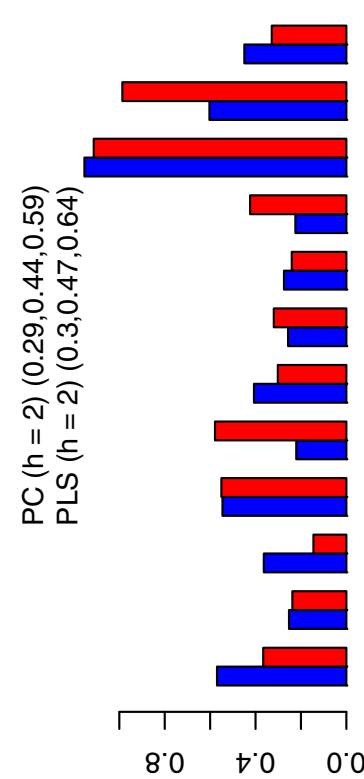

Ј

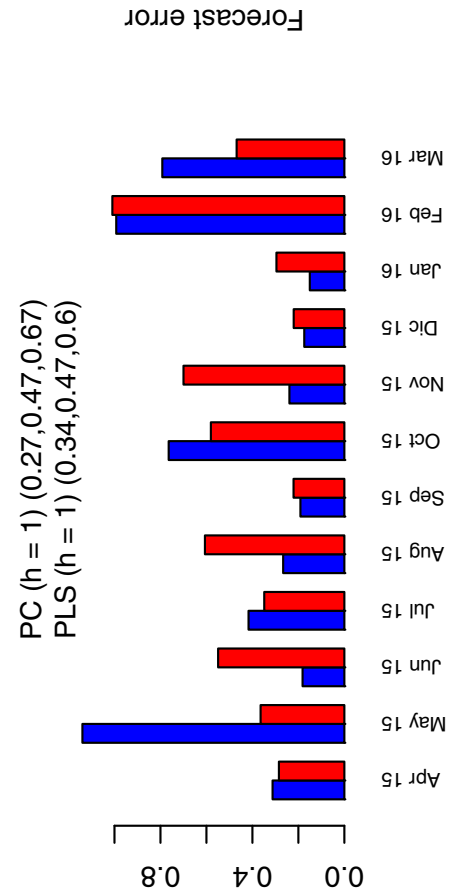

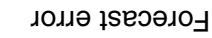

9) $d \mathrm{~d} \forall$

91 qә]

9t uer

Sเ ग!ด

Sเ $\wedge$ ON

St 100

st des

st $6 n \forall$

St In

St une

St KeW

\section{0}

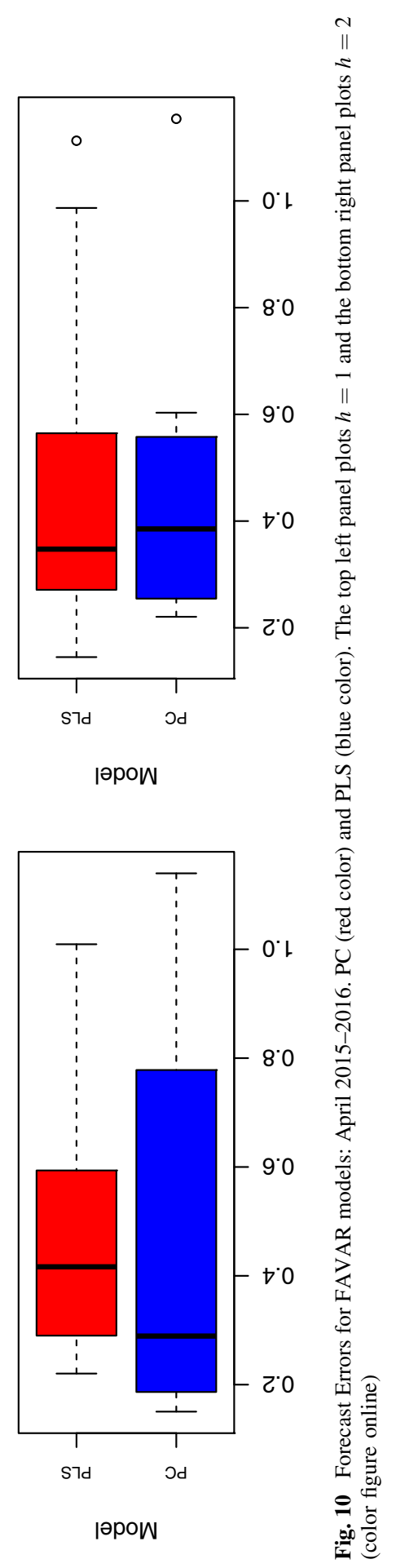


Robustness of the selected models $h=1$

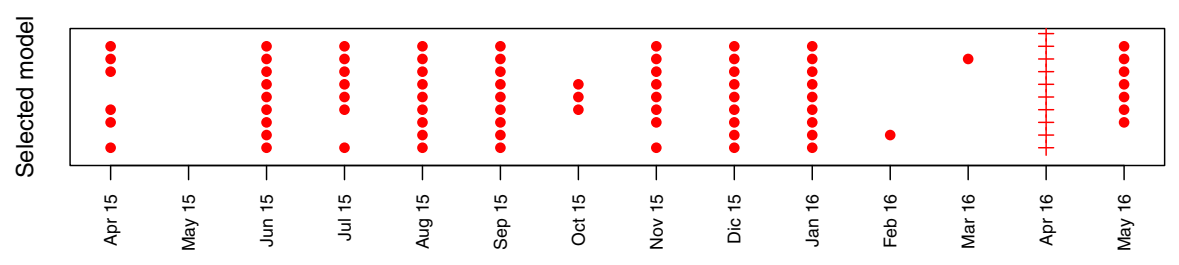

Robustness of the selected models $h=2$

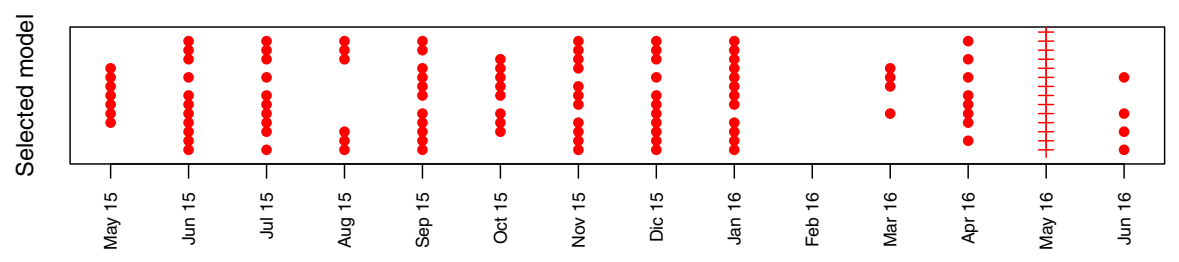

Fig. 11 Robustness of selected models. Red points indicate that the model satisfies the empirical threshold in the specific forecast month. A red cross indicates that there is no information to compute the statistic (color figure online)

Economically, the more relevant groups of variables in the determination of the common trends are the miscellaneous group, the economic activity, balance of trade, and the industrial sector. The first group of variables basically comprises tourism information and variables related to the automotive industry. In this context, the behaviors of the external sector and internal demand are very important to predict the behavior of the global economy. It is reasonable to expect that external uncertainty and disincentives in the internal market can be dangerous for future economic growth. In other words, these groups of variables indicate the future movements of Mexican economic activity.

A future line of research is to use the common trends in factor error correction models (FECM), and FAVAR with time-varying coefficients, among many other models, combining the predictions with different combinations of forecasting methods. Furthermore, we consider a unit root test that takes into account the structural break that occurred between 2008 and 2009 in order to refine the procedure to select $I(1)$ variables. Consequently, it is interesting to study the non-stationarity of the estimated common factors in the presence of breaks. Additionally, we will take into account the possibility of sparse cointegration for forecasting proposes.

Acknowledgements Partial financial support from the CONACYT CB-2015-01-252996 is gratefully acknowledged.

Open Access This article is distributed under the terms of the Creative Commons Attribution 4.0 International License (http://creativecommons.org/licenses/by/4.0/), which permits unrestricted use, distribution, and reproduction in any medium, provided you give appropriate credit to the original author(s) and the source, provide a link to the Creative Commons license, and indicate if changes were made. 
Annex: Variables in the dynamic factor model

\begin{tabular}{|c|c|c|c|c|c|c|}
\hline \# & Short & Long & Block & $\log$ & SA & $T$ \\
\hline 1 & EXP TOT & Total absolute value exports & $\begin{array}{l}\text { Balance of } \\
\text { trade }\end{array}$ & Yes & Yes & 1 \\
\hline 2 & $\begin{array}{l}\text { EXP PET } \\
\text { TOT }\end{array}$ & Oil exports & $\begin{array}{l}\text { Balance of } \\
\text { trade }\end{array}$ & Yes & Yes & 1 \\
\hline 3 & $\begin{array}{l}\text { EXP PET } \\
\text { CRU }\end{array}$ & Crude oil exports & $\begin{array}{l}\text { Balance of } \\
\text { trade }\end{array}$ & Yes & Yes & 1 \\
\hline 4 & $\begin{array}{l}\text { EXP PET } \\
\text { OTR }\end{array}$ & Other oil exports & $\begin{array}{l}\text { Balance of } \\
\text { trade }\end{array}$ & Yes & Yes & 1 \\
\hline 5 & EXP NO PET & Non-oil exports & $\begin{array}{l}\text { Balance of } \\
\text { trade }\end{array}$ & Yes & Yes & 1 \\
\hline 6 & $\begin{array}{l}\text { EXP NO PET } \\
\text { AGR }\end{array}$ & Farming exports & $\begin{array}{l}\text { Balance of } \\
\text { trade }\end{array}$ & Yes & Yes & 1 \\
\hline 7 & $\begin{array}{l}\text { EXP NO PET } \\
\text { EXTRAC }\end{array}$ & Extractive exports & $\begin{array}{l}\text { Balance of } \\
\text { trade }\end{array}$ & Yes & Yes & 1 \\
\hline 8 & $\begin{array}{l}\text { EXP MAN } \\
\text { AUT }\end{array}$ & Automotive exports & $\begin{array}{l}\text { Balance of } \\
\text { trade }\end{array}$ & Yes & Yes & 1 \\
\hline 9 & $\begin{array}{l}\text { EXP NO } \\
\text { MAN RES }\end{array}$ & Manufacture exports & $\begin{array}{l}\text { Balance of } \\
\text { trade }\end{array}$ & Yes & Yes & 1 \\
\hline 10 & $\begin{array}{l}\text { IMP TOT } \\
\text { PET }\end{array}$ & Total oil imports & $\begin{array}{l}\text { Balance of } \\
\text { trade }\end{array}$ & Yes & Yes & 1 \\
\hline 11 & $\begin{array}{l}\text { IMP CON } \\
\text { TOT }\end{array}$ & Consumption goods imports & $\begin{array}{l}\text { Balance of } \\
\text { trade }\end{array}$ & Yes & Yes & 1 \\
\hline 12 & $\begin{array}{l}\text { IMP CON } \\
\text { PET }\end{array}$ & Consumption goods oil imports & $\begin{array}{l}\text { Balance of } \\
\text { trade }\end{array}$ & Yes & No & 1 \\
\hline 13 & $\begin{array}{r}\text { IMP CON } \\
\text { NO PET }\end{array}$ & Consumption goods non-oil imports & $\begin{array}{l}\text { Balance of } \\
\text { trade }\end{array}$ & Yes & Yes & 1 \\
\hline 14 & IMP INT PET & Intermediate goods oil imports & $\begin{array}{l}\text { Balance of } \\
\text { trade }\end{array}$ & Yes & Yes & 1 \\
\hline 15 & IMP BK & Capital goods imports & $\begin{array}{l}\text { Balance of } \\
\text { trade }\end{array}$ & Yes & Yes & 1 \\
\hline 16 & REM TOT & Total remittances & $\begin{array}{l}\text { Balance of } \\
\text { trade }\end{array}$ & Yes & Yes & 1 \\
\hline 17 & REM MO & Money orders remittances & $\begin{array}{l}\text { Balance of } \\
\text { trade }\end{array}$ & Yes & Yes & 1 \\
\hline 18 & $\begin{array}{l}\text { REM TRANS } \\
\text { ELECT }\end{array}$ & Electronic transfers remittances & $\begin{array}{l}\text { Balance of } \\
\text { trade }\end{array}$ & Yes & Yes & 1 \\
\hline 19 & REM EFEC & Cash and in-kind remittances & $\begin{array}{l}\text { Balance of } \\
\text { trade }\end{array}$ & Yes & Yes & 1 \\
\hline 20 & I CONF & Consumer confidence index & $\begin{array}{l}\text { Consumer } \\
\text { confidence }\end{array}$ & Yes & Yes & 1 \\
\hline 21 & $\begin{array}{l}\text { I CONF } \\
\text { COMP } \\
\text { HOG } 12\end{array}$ & $\begin{array}{l}\text { Index: compared to this household's economic } \\
\text { situation } 12 \text { months ago, how do you think } \\
\text { your situation is at the moment? }\end{array}$ & $\begin{array}{l}\text { Consumer } \\
\text { confidence }\end{array}$ & Yes & Yes & 1 \\
\hline 22 & $\begin{array}{l}\text { I CONF FUT } \\
\text { COMP PAI } \\
12\end{array}$ & $\begin{array}{l}\text { Index: how do you foresee this household's } \\
\text { economic situation in } 12 \text { months' time, } \\
\text { compared to the current situation? }\end{array}$ & $\begin{array}{l}\text { Consumer } \\
\text { confidence }\end{array}$ & Yes & Yes & 2 \\
\hline
\end{tabular}


continued

\begin{tabular}{|c|c|c|c|c|c|c|}
\hline$\#$ & Short & Long & Block & $\log$ & SA & $T$ \\
\hline 23 & $\begin{array}{l}\text { I CONF } \\
\text { COMP PAI } \\
12\end{array}$ & $\begin{array}{l}\text { Index: how do you consider the country's } \\
\text { economic situation today compared to } \\
12 \text { months ago? }\end{array}$ & $\begin{array}{l}\text { Consumer } \\
\text { confidence }\end{array}$ & Yes & Yes & 1 \\
\hline 24 & $\begin{array}{l}\text { I CONF FUT } \\
\text { COMP PAI } \\
12\end{array}$ & $\begin{array}{l}\text { Index: how do you foresee the country's } \\
\text { economic situation in } 12 \text { months' time? }\end{array}$ & $\begin{array}{l}\text { Consumer } \\
\text { confidence }\end{array}$ & Yes & Yes & 1 \\
\hline 25 & $\begin{array}{l}\text { I CONF POS } \\
\text { FUT }\end{array}$ & $\begin{array}{l}\text { Index: comparing the current economic } \\
\text { situation with that of a year ago, how do you } \\
\text { consider at the present moment the } \\
\text { possibilities that you or any of the members } \\
\text { of this household }\end{array}$ & $\begin{array}{l}\text { Consumer } \\
\text { confidence }\end{array}$ & Yes & Yes & 1 \\
\hline 26 & I CONF B & Consumer confidence index (balance) & $\begin{array}{l}\text { Consumer } \\
\text { confidence }\end{array}$ & Yes & Yes & 2 \\
\hline 27 & COMP 12 B & $\begin{array}{l}\text { Other complementary index: how would you } \\
\text { describe your economic situation compared } \\
\text { to } 12 \text { months ago? }\end{array}$ & $\begin{array}{l}\text { Consumer } \\
\text { confidence }\end{array}$ & Yes & Yes & 1 \\
\hline 28 & FUT 12 B & $\begin{array}{l}\text { Other complementary index: and how do you } \\
\text { think your economic situation will be in } \\
12 \text { months, compared to the current } \\
\text { situation? }\end{array}$ & $\begin{array}{l}\text { Consumer } \\
\text { confidence }\end{array}$ & Yes & Yes & 1 \\
\hline 29 & POSI 12 & $\begin{array}{l}\text { Other complementary index: at this moment, } \\
\text { are you more able to buy clothes, shoes, food, } \\
\text { etc., than a year ago? }\end{array}$ & $\begin{array}{l}\text { Consumer } \\
\text { confidence }\end{array}$ & Yes & Yes & 1 \\
\hline 30 & $\begin{array}{l}\text { POSI } 12 \\
\text { VAC }\end{array}$ & $\begin{array}{l}\text { Other complementary index: do you consider } \\
\text { that during the next } 12 \text { months you or any of } \\
\text { the members of this household will afford to } \\
\text { go on vacation? }\end{array}$ & $\begin{array}{l}\text { Consumer } \\
\text { confidence }\end{array}$ & Yes & Yes & 1 \\
\hline 31 & POS AHO & $\begin{array}{l}\text { Other complementary index: are you currently } \\
\text { able to save some of your income? }\end{array}$ & $\begin{array}{l}\text { Consumer } \\
\text { confidence }\end{array}$ & Yes & Yes & 1 \\
\hline 32 & COMP C 12 & $\begin{array}{l}\text { Other complementary index: how do you } \\
\text { foresee your economic conditions to save in } \\
12 \text { months' time compared to current } \\
\text { conditions? }\end{array}$ & $\begin{array}{l}\text { Consumer } \\
\text { confidence }\end{array}$ & Yes & Yes & 1 \\
\hline 33 & COMP PRE & $\begin{array}{l}\text { Other complementary index: compared with } \\
\text { the previous } 12 \text { months, how do you think } \\
\text { prices will behave in the country in the next } \\
12 \text { months? }\end{array}$ & $\begin{array}{l}\text { Consumer } \\
\text { confidence }\end{array}$ & Yes & Yes & 1 \\
\hline 34 & $\begin{array}{l}\text { COMP } 12 \\
\text { EMP }\end{array}$ & $\begin{array}{l}\text { Other complementary index: do you think that } \\
\text { employment in the country in the next } \\
12 \text { months is going to increase, remain the } \\
\text { same, or decrease? }\end{array}$ & $\begin{array}{l}\text { Consumer } \\
\text { confidence }\end{array}$ & Yes & Yes & 1 \\
\hline 35 & AUT 12 & $\begin{array}{l}\text { Other supplemental index: are any members of } \\
\text { this household or you planning to buy a new } \\
\text { or used car in the next } 2 \text { years? }\end{array}$ & $\begin{array}{l}\text { Consumer } \\
\text { confidence }\end{array}$ & Yes & Yes & 1 \\
\hline 36 & PLA AUT 2 & $\begin{array}{l}\text { Other complementary index: are any members } \\
\text { of this household or you planning to buy, } \\
\text { build or remodel a home in the next } 2 \text { years? }\end{array}$ & $\begin{array}{l}\text { Consumer } \\
\text { confidence }\end{array}$ & Yes & Yes & 1 \\
\hline
\end{tabular}


continued

\begin{tabular}{lll}
\hline$\#$ & Short & Long
\end{tabular}

$\begin{array}{ll}38 & \text { IVF } \\ 39 & \text { IVFBST } \\ 40 & \text { IVFB }\end{array}$

41 IVFS

42 IVFBI

43 IVFAT

44 IVFNB

45 IVFNS

46 IVFBIMP

47 IGAE A 1

48 IGAE A 2

49 IGAE A 21

50 IGAE A 22

51 IGAE A 31-33

52 IGAE A 3

53 IGAE A

$$
\text { 43-46 }
$$

54 IGAE A 48 4951

55 IGAE A $52-53$

56 IGAE A 54-56

57 IGAE A 61-62

58 IGAE A 71-81
Physical volume index total

IVF goods and services of national origin total

IVF goods and services of national origin goods

IVF goods and services of national origin services

IVF imported goods

IVF total accumulative

IVFAT goods and services of national origin goods

IVFAT goods and services of national origin services

IVFAT imported goods

IGAE primary activities

IGAE secondary activities total

IGAE secondary activities 21 mining

IGAE secondary activities 22

IGAE secondary activities 31-33

IGAE tertiary activities total

IGAE tertiary activities 43-46 trade

IGAE tertiary activities 48-49-51. Transport, mail, and storage; mass media information

IGAE tertiary activities 52-53 financial and insurance services; real estate and rental services of movable and intangible goods

IGAE tertiary activities 54-55-56 professional, scientific and technical services; corporate; business support services and waste management and remediation services

IGAE tertiary activities 61-62 educational services; health and social work services

IGAE tertiary activities 71-81 cultural and sporting recreation services, and other recreational services; other services except government activities

$\begin{array}{llll}\text { Block } & \text { Log } & \text { SA } & T \\ \begin{array}{c}\text { Consumer } \\ \text { confidence }\end{array} & \text { Yes } & \text { Yes } & 1 \\ & & & \end{array}$

Consumption Yes Yes 2

Consumption Yes Yes 2

Consumption Yes Yes 1

Consumption Yes Yes 2

Consumption Yes Yes 1

Consumption Yes Yes 1

Consumption Yes Yes 1

Consumption Yes Yes 2

Consumption Yes Yes 1

Economic Yes Yes 1 activity

$\begin{array}{cccc}\begin{array}{c}\text { Economic } \\ \text { activity }\end{array} & \text { Yes } & \text { Yes } 1 \\ & & & \end{array}$

Economic Yes Yes 1 activity

Economic Yes Yes 1 activity

Economic Yes Yes 1 activity

Economic Yes Yes 1 activity

Economic Yes Yes 1 activity

Economic Yes Yes 2

activity

Economic $\quad$ Yes Yes 1 activity

Economic Yes Yes 2 activity

$\begin{array}{llll}\begin{array}{c}\text { Economic } \\ \text { activity }\end{array} & \text { Yes } & \text { Yes } & 1 \\ \begin{array}{c}\text { Economic } \\ \text { activity }\end{array} & \text { Yes } & \text { Yes } & 2 \\ & & & \end{array}$


continued

\begin{tabular}{|c|c|c|c|c|c|c|}
\hline$\#$ & Short & Long & Block & $\log$ & SA & $T$ \\
\hline 59 & IGAE 72 & $\begin{array}{l}\text { IGAE tertiary activities } 72 \text { temporary } \\
\text { accommodation and food and beverage } \\
\text { preparation services }\end{array}$ & $\begin{array}{c}\text { Economic } \\
\text { activity }\end{array}$ & Yes & Yes & 1 \\
\hline 60 & PEO & $\begin{array}{l}\text { Economically active population: occupied } \\
\text { population }\end{array}$ & Employment & Yes & Yes & 1 \\
\hline 61 & PED & $\begin{array}{l}\text { Economically active population: unemployed } \\
\text { population }\end{array}$ & Employment & Yes & Yes & 1 \\
\hline 62 & PO S AGR & $\begin{array}{l}\text { Occupied population by agriculture economic } \\
\text { activity sector }\end{array}$ & Employment & Yes & Yes & 1 \\
\hline 63 & PO CONS & $\begin{array}{l}\text { Occupied population by construction economic } \\
\text { activity sector }\end{array}$ & Employment & Yes & Yes & 1 \\
\hline 64 & PO MAN & $\begin{array}{l}\text { Occupied population by manufacturing } \\
\text { industry economic activity sector }\end{array}$ & Employment & Yes & Yes & 1 \\
\hline 65 & TIIE & $\begin{array}{l}\text { Interbank interest rates, bank collection costs, } \\
\text { and CETES performance Interbank interest } \\
\text { rate (TIIE) }\end{array}$ & Financial & Yes & Yes & 1 \\
\hline 66 & CETES & $\begin{array}{l}\text { Interbank interest rates, bank funding costs, } \\
\text { and CETES performance cost of time } \\
\text { deposits of liabilities denominated in US } \\
\text { dollars (CCP-dollars) }\end{array}$ & Financial & Yes & Yes & 1 \\
\hline 67 & $\mathrm{TC}$ & $\begin{array}{l}\text { Exchange rate of peso against dollar and UDIS } \\
\text { value Interbank (sale) }\end{array}$ & Financial & Yes & Yes & 1 \\
\hline 68 & I TC R & Mexican peso real exchange rate index & Financial & Yes & Yes & 1 \\
\hline 69 & I TC R VAR & $\begin{array}{l}\text { Mexican peso real exchange rate index annual } \\
\text { change }\end{array}$ & Financial & No & No & 1 \\
\hline 70 & IPCBMV & $\begin{array}{l}\text { Index of prices and quotes of the Mexican } \\
\text { stock exchange maximum }\end{array}$ & Financial & Yes & No & 1 \\
\hline 71 & TIIL & International interest rates: Libor rate & Financial & Yes & No & 1 \\
\hline 72 & M1 & M1 money and coins held by the public & Financial & Yes & Yes & 2 \\
\hline 73 & M1 CB & $\begin{array}{l}\text { M1 foreign currency checking accounts at } \\
\text { resident banks }\end{array}$ & Financial & Yes & Yes & 2 \\
\hline 74 & M1 DAP & $\begin{array}{l}\text { M1 demand deposits of savings and loan } \\
\text { companies }\end{array}$ & Financial & Yes & Yes & 1 \\
\hline 75 & M2 CIRT & Internal funding of resident banks total & Financial & Yes & Yes & 1 \\
\hline 76 & M2 CIBR & Domestic funding from resident banks & Financial & Yes & No & 1 \\
\hline 77 & M2 CIBR ME & $\begin{array}{l}\text { Internal collection of resident banks in foreign } \\
\text { currency }\end{array}$ & Financial & Yes & Yes & 1 \\
\hline 78 & M2 VP GF & $\begin{array}{l}\text { Securities issued by the Federal Government } \\
\text { total }\end{array}$ & Financial & Yes & Yes & 1 \\
\hline 79 & IPAB & IPAB total & Financial & Yes & Yes & 1 \\
\hline 80 & IPAB S & IPAB securities held by the siefores & Financial & Yes & Yes & 1 \\
\hline 81 & IPAB EPP & $\begin{array}{l}\text { IPAB securities held by public and private } \\
\text { companies }\end{array}$ & Financial & Yes & Yes & 1 \\
\hline 82 & $\begin{array}{l}\text { M2 } \\
\text { SIEFORES }\end{array}$ & Other public securities held by the siefores & Financial & Yes & Yes & 1 \\
\hline
\end{tabular}




\begin{tabular}{|c|c|c|c|c|c|c|}
\hline$\#$ & Short & Long & Block & $\log$ & SA & $T$ \\
\hline 83 & M2 EPP & $\begin{array}{l}\text { Other public securities owned by public and } \\
\text { private companies }\end{array}$ & Financial & Yes & Yes & 1 \\
\hline 84 & M2 V P T & Private securities total & Financial & Yes & Yes & 1 \\
\hline 85 & $\begin{array}{l}\text { M2 V P } \\
\text { SIEFORES }\end{array}$ & Private securities held by the siefores & Financial & Yes & No & 1 \\
\hline 86 & M2 V P EPP & $\begin{array}{l}\text { Private securities owned by public and private } \\
\text { companies }\end{array}$ & Financial & Yes & Yes & 2 \\
\hline 87 & $\begin{array}{l}\text { FON F } \\
\text { SIEFORES }\end{array}$ & $\begin{array}{l}\text { Savings funds for withdrawal from SIEFORES } \\
\text { total }\end{array}$ & Financial & Yes & Yes & 1 \\
\hline 88 & $\begin{array}{l}\text { FON F } \\
\text { SIEFORES } \\
\text { BM }\end{array}$ & Retirement funds at the Banco de Mexico total & Financial & Yes & Yes & 1 \\
\hline 89 & SIEFORES & Retirement funds at the Banco de Mexico total & Financial & Yes & Yes & 1 \\
\hline 90 & M3 & $\begin{array}{l}\text { Domestic financial assets held by non-residents } \\
\text { total }\end{array}$ & Financial & Yes & No & 2 \\
\hline 91 & M3 BRT & Collection of resident banks total & Financial & Yes & Yes & 1 \\
\hline 92 & M3 BRMN & $\begin{array}{l}\text { Collection of resident banks in national } \\
\text { currency }\end{array}$ & Financial & Yes & Yes & 1 \\
\hline 93 & M3 BRME & $\begin{array}{l}\text { Collection of resident banks in foreign } \\
\text { currency }\end{array}$ & Financial & Yes & Yes & 1 \\
\hline 94 & M3 VP T & $\begin{array}{l}\text { Government securities held by non-residents } \\
\text { total }\end{array}$ & Financial & Yes & No & 2 \\
\hline 95 & M3 GF & $\begin{array}{l}\text { Securities issued by the Federal Government } \\
\text { total }\end{array}$ & Financial & Yes & Yes & 2 \\
\hline 96 & M3 IPAB & $\begin{array}{l}\text { Public securities held by non-residents } \\
\text { securities issued by the IPAB }\end{array}$ & Financial & Yes & Yes & 1 \\
\hline 97 & M4 & $\begin{array}{l}\text { Acquisition of branches and agencies of } \\
\text { Mexican banks abroad total }\end{array}$ & Financial & Yes & Yes & 1 \\
\hline 98 & M4 DR & Deposits of residents total & Financial & Yes & Yes & 1 \\
\hline 99 & M4 DNR & Deposits of non-residents total & Financial & Yes & No & 1 \\
\hline 100 & IVFI 212 & $\begin{array}{l}\text { Mining of metallic and non-metallic minerals, } \\
\text { except oil and gas }\end{array}$ & Industrial & Yes & Yes & 1 \\
\hline 101 & IVFI 213 & Mining-related services & Industrial & Yes & Yes & 1 \\
\hline 102 & IVFI 23 & Construction total & Industrial & Yes & Yes & 2 \\
\hline 103 & IVFI 237 & Construction of civil engineering works & Industrial & Yes & Yes & 2 \\
\hline 104 & IVFI 238 & Specialized construction works & Industrial & Yes & Yes & 1 \\
\hline 105 & IVFI 311 & Manufacturing 311 industry & Industrial & Yes & Yes & 2 \\
\hline 106 & IVFI 312 & $\begin{array}{l}\text { Manufacturing } 312 \text { beverages and tobacco } \\
\text { industry }\end{array}$ & Industrial & Yes & Yes & 1 \\
\hline 107 & IVFI 313 & $\begin{array}{l}\text { Manufacturing } 313 \text { manufacture of textiles and } \\
\text { textile finishing }\end{array}$ & Industrial & Yes & Yes & 1 \\
\hline 108 & IVFI 314 & $\begin{array}{l}\text { Manufacturing } 314 \text { manufacture of textiles, } \\
\text { except apparel }\end{array}$ & Industrial & Yes & Yes & 1 \\
\hline 109 & IVFI 315 & Manufacturing 315 manufacture of clothing & Industrial & Yes & Yes & 1 \\
\hline
\end{tabular}


continued

\begin{tabular}{|c|c|c|c|c|c|c|}
\hline$\#$ & Short & Long & Block & $\log$ & SA & $T$ \\
\hline 110 & IVFI 316 & $\begin{array}{l}\text { Manufacturing } 316 \text { tanning and finishing of } \\
\text { leather, manufacture of leather and leather } \\
\text { substitutes materials }\end{array}$ & Industrial & Yes & Yes & 1 \\
\hline 111 & IVFI 321 & Manufacturing 321 wood industry & Industrial & Yes & Yes & 1 \\
\hline 112 & IVFI 322 & Manufacturing 322 paper industry & Industrial & Yes & Yes & 1 \\
\hline 113 & IVFI 323 & $\begin{array}{l}\text { Manufacturing } 323 \text { printing and related } \\
\text { industries }\end{array}$ & Industrial & Yes & Yes & 1 \\
\hline 114 & IVFI 324 & $\begin{array}{l}\text { Manufacturing } 324 \text { manufacture of petroleum } \\
\text { products and coal }\end{array}$ & Industrial & Yes & Yes & 1 \\
\hline 115 & IVFI 325 & $\begin{array}{l}\text { Manufacturing industries } 325 \text { chemical } \\
\text { industry }\end{array}$ & Industrial & Yes & Yes & 1 \\
\hline 116 & IVFI 326 & Manufacturing 326 Plastic and rubber industry & Industrial & Yes & Yes & 1 \\
\hline 117 & IVFI 327 & $\begin{array}{l}\text { Manufacturing } 327 \text { manufacture of non- } \\
\text { metallic mineral products }\end{array}$ & Industrial & Yes & Yes & 1 \\
\hline 118 & IVFI 331 & $\begin{array}{l}\text { Manufacturing industries } 331 \text { basic metal } \\
\text { industries }\end{array}$ & Industrial & Yes & Yes & 1 \\
\hline 119 & IVFI 332 & $\begin{array}{l}\text { Manufacturing } 332 \text { manufacture of metal } \\
\text { products }\end{array}$ & Industrial & Yes & Yes & 1 \\
\hline 120 & IVFI 333 & $\begin{array}{l}\text { Manufacturing } 333 \text { manufacture of machinery } \\
\text { and equipment }\end{array}$ & Industrial & Yes & Yes & 1 \\
\hline 121 & IVFI 334 & $\begin{array}{l}\text { Manufacturing } 334 \text { manufacture of computer } \\
\text { equipment, communication, measurement } \\
\text { and other electronic equipment, components } \\
\text { and accessories }\end{array}$ & Industrial & Yes & Yes & 1 \\
\hline 122 & IVFI 335 & $\begin{array}{l}\text { Manufacturing } 335 \text { manufacture of electrical } \\
\text { fittings, electrical apparatus, and electric } \\
\text { power generation equipment }\end{array}$ & Industrial & Yes & Yes & 1 \\
\hline 123 & IVFI 336 & $\begin{array}{l}\text { Manufacturing } 336 \text { manufacture of transport } \\
\text { equipment }\end{array}$ & Industrial & Yes & Yes & 1 \\
\hline 124 & IVFI 337 & $\begin{array}{l}\text { Manufacturing } 337 \text { manufacture of furniture, } \\
\text { mattresses, and blinds }\end{array}$ & Industrial & Yes & Yes & 1 \\
\hline 125 & IVFI 339 & $\begin{array}{l}\text { Manufacturing } 339 \text { other industrial } \\
\text { manufacturing }\end{array}$ & Industrial & Yes & Yes & 1 \\
\hline 126 & IVFIA & Accumulated total of industrial activity & Industrial & Yes & Yes & 1 \\
\hline 127 & IVFIA 21 & Accumulated mining total mining & Industrial & Yes & Yes & 1 \\
\hline 128 & IVFIA 212 & $\begin{array}{l}\text { Accumulated mining of metallic and non- } \\
\text { metallic minerals, other than oil and gas }\end{array}$ & Industrial & Yes & Yes & 1 \\
\hline 129 & IVFIA 213 & Accumulated mining-related services & Industrial & Yes & Yes & 1 \\
\hline 130 & IVFIA 22 & $\begin{array}{l}\text { Accumulated total generation, transmission and } \\
\text { distribution of electricity, water and gas } \\
\text { supply by pipelines to the final consumer }\end{array}$ & Industrial & Yes & Yes & 1 \\
\hline 131 & IVFIA 222 & $\begin{array}{l}\text { Accumulated Water supply and piped gas } \\
\text { supply to the final consumer }\end{array}$ & Industrial & Yes & Yes & 1 \\
\hline 132 & IVFIA 23 & Accumulated construction total & Industrial & Yes & Yes & 1 \\
\hline 133 & IVFIA 236 & Accumulated building & Industrial & Yes & Yes & 1 \\
\hline 134 & IVFIA 237 & $\begin{array}{l}\text { Accumulated construction of civil engineering } \\
\text { works }\end{array}$ & Industrial & Yes & Yes & 1 \\
\hline
\end{tabular}


continued

\begin{tabular}{|c|c|c|c|c|c|c|}
\hline$\#$ & Short & Long & Block & $\log$ & SA & $T$ \\
\hline 135 & IVFIA 238 & Accumulated specialized construction work & Industrial & Yes & Yes & 1 \\
\hline 136 & IVFIA $31-33$ & Accumulated manufacturing industry total & Industrial & Yes & Yes & 1 \\
\hline 137 & IVFIA 311 & Accumulated 311 food industry & Industrial & Yes & Yes & 1 \\
\hline 138 & IVFIA 312 & $\begin{array}{l}\text { Accumulated } 312 \text { beverages and tobacco } \\
\text { industry }\end{array}$ & Industrial & Yes & Yes & 1 \\
\hline 139 & IVFIA 313 & Accumulated manufacturing industry 313 & Industrial & Yes & Yes & 1 \\
\hline 140 & IVFIA 314 & Accumulated manufacturing industry 314 & Industrial & Yes & Yes & 1 \\
\hline 141 & IVFIA 315 & Accumulated manufacturing industry 315 & Industrial & Yes & Yes & 1 \\
\hline 142 & IVFIA 316 & $\begin{array}{l}\text { Accumulated manufacturing industry } 316 \\
\text { tanning and finishing of leather }\end{array}$ & Industrial & Yes & Yes & 1 \\
\hline 143 & IVFIA 321 & Accumulated manufacturing industry 321 & Industrial & Yes & Yes & 1 \\
\hline 144 & IVFIA 322 & $\begin{array}{l}\text { Accumulated manufacturing } 322 \text { Paper } \\
\text { industry }\end{array}$ & Industrial & Yes & Yes & 1 \\
\hline 145 & IVFIA 323 & $\begin{array}{l}\text { Accumulated manufacturing } 323 \text { printing and } \\
\text { related industries }\end{array}$ & Industrial & Yes & Yes & 1 \\
\hline 146 & IVFIA 324 & $\begin{array}{l}\text { Accumulated manufacturing } 324 \text { manufacture } \\
\text { of petroleum products and coal }\end{array}$ & Industrial & Yes & Yes & 1 \\
\hline 147 & IVFIA 325 & $\begin{array}{l}\text { Accumulated manufacturing industries } 325 \\
\text { chemical industry }\end{array}$ & Industrial & Yes & Yes & 1 \\
\hline 148 & IVFIA 326 & $\begin{array}{l}\text { Accumulated manufacturing } 326 \text { plastic and } \\
\text { rubber industry }\end{array}$ & Industrial & Yes & Yes & 1 \\
\hline 149 & IVFIA 327 & $\begin{array}{l}\text { Accumulated manufacturing } 327 \text { manufacture } \\
\text { of non-metallic mineral products }\end{array}$ & Industrial & Yes & Yes & 1 \\
\hline 150 & IVFIA 331 & $\begin{array}{l}\text { Accumulated manufacturing } 331 \text { basic metal } \\
\text { industries }\end{array}$ & Industrial & Yes & Yes & 1 \\
\hline 151 & IVFIA 332 & $\begin{array}{l}\text { Accumulated manufacturing } 332 \text { manufacture } \\
\text { of metal products }\end{array}$ & Industrial & Yes & Yes & 1 \\
\hline 152 & IVFIA 333 & $\begin{array}{l}\text { Accumulated manufacturing } 333 \text { manufacture } \\
\text { of machinery and equipment }\end{array}$ & Industrial & Yes & Yes & 1 \\
\hline 153 & IVFIA 334 & $\begin{array}{l}\text { Accumulated manufacturing } 334 \text { manufacture } \\
\text { of computer, communication, measurement } \\
\text { and other electronic equipment, components, } \\
\text { and accessories }\end{array}$ & Industrial & Yes & Yes & 1 \\
\hline 154 & IVFIA 335 & $\begin{array}{l}\text { Accumulated manufacturing } 335 \text { manufacture } \\
\text { of accessories, electrical apparatus, and } \\
\text { electric power generation equipment }\end{array}$ & Industrial & Yes & Yes & 1 \\
\hline 155 & IVFIA 336 & $\begin{array}{l}\text { Accumulated manufacturing } 336 \text { manufacture } \\
\text { of transport equipment }\end{array}$ & Industrial & Yes & Yes & 1 \\
\hline 156 & IVFIA 337 & $\begin{array}{l}\text { Accumulated manufacturing } 337 \text { manufacture } \\
\text { of furniture, mattresses, and blinds }\end{array}$ & Industrial & Yes & Yes & 1 \\
\hline 157 & IVFIA 339 & $\begin{array}{l}\text { Accumulated manufacturing } 339 \text { other } \\
\text { manufacturing }\end{array}$ & Industrial & Yes & Yes & 1 \\
\hline 158 & IPI EUA & Indices of United States industrial production & International & Yes & Yes & 1 \\
\hline 159 & TD EUA & United States unemployment rates & International & Yes & No & 2 \\
\hline 160 & OM EUA & United States monetary offer & International & Yes & No & 2 \\
\hline 161 & TI $3 \mathrm{M}$ & Interest rate USA 3 months & International & Yes & Yes & 1 \\
\hline
\end{tabular}




\begin{tabular}{|c|c|c|c|c|c|c|}
\hline$\#$ & Short & Long & Block & $\log$ & SA & $T$ \\
\hline 162 & TI $6 \mathrm{M}$ & Interest rate USA 6 months & International & Yes & Yes & 1 \\
\hline 163 & TI $1 \mathrm{M}$ & Interest rate USA 1 year & International & No & Yes & 2 \\
\hline 164 & TI $2 \mathrm{~A}$ & Interest rate USA 2 years & International & Yes & No & 1 \\
\hline 165 & TI $3 \mathrm{~A}$ & Interest rate USA 3 years & International & Yes & No & 1 \\
\hline 166 & TI $5 \mathrm{~A}$ & Interest rate USA 5 years & International & Yes & No & 1 \\
\hline 167 & TI $10 \mathrm{~A}$ & Interest rate USA 10 years & International & Yes & No & 1 \\
\hline 168 & TI 20 & Interest rate USA 20 years & International & Yes & No & 1 \\
\hline 169 & TI FF & Interest rate USA federal funds & International & Yes & No & 1 \\
\hline 170 & $\begin{array}{l}\text { I REMUN } \\
\text { EUA }\end{array}$ & Manufacturing remunerations USA & International & Yes & Yes & 2 \\
\hline 171 & RESER EUA & Total reserves (not including gold) USA & International & Yes & No & 1 \\
\hline 172 & EXP EUA & Total exports USA & International & Yes & No & 1 \\
\hline 173 & IMP EUA & Total imports USA & International & Yes & No & 1 \\
\hline 174 & BC EUA & Balance of trade USA & International & No & No & 1 \\
\hline 175 & INV T & Investment total & Investment & Yes & Yes & 1 \\
\hline 176 & INV CON & Investment residential & Investment & Yes & Yes & 2 \\
\hline 177 & $\begin{array}{l}\text { INV CON } \\
\text { NR }\end{array}$ & Investment non-residential & Investment & Yes & Yes & 2 \\
\hline 178 & INV MET & Investment total machines and equipment & Investment & Yes & Yes & 1 \\
\hline 179 & INV ME & Investment machines and equipment & Investment & Yes & Yes & 1 \\
\hline 180 & INV MEO & Investment machines, equipment, and others & Investment & Yes & Yes & 1 \\
\hline 181 & INV MET & Investment transporting equipment (imported) & Investment & Yes & Yes & 1 \\
\hline 182 & INV MAEO & $\begin{array}{l}\text { Investment machines, equipment and others } \\
\text { (imported) }\end{array}$ & Investment & Yes & Yes & 1 \\
\hline 183 & TUR VS & Total balance & Miscellaneous & Yes & Yes & 1 \\
\hline 184 & TUR IT & Total income & Miscellaneous & Yes & Yes & 1 \\
\hline 185 & TUR TI & International tourists & Miscellaneous & Yes & Yes & 1 \\
\hline 186 & TUR ET & Total expenditure & Miscellaneous & Yes & Yes & 1 \\
\hline 187 & TUR TIT & Total expenditure (international tourists) & Miscellaneous & Yes & Yes & 1 \\
\hline 188 & TUR VIT & Total income (volume) & Miscellaneous & Yes & Yes & 1 \\
\hline 189 & TUR ITIT & Total income (international tourists) & Miscellaneous & Yes & Yes & 1 \\
\hline 190 & TUR ET V & Total expenditure (volume) & Miscellaneous & Yes & Yes & 1 \\
\hline 191 & TUR ET TUT & Total expenditure (international tourists) & Miscellaneous & Yes & Yes & 1 \\
\hline 192 & TUR GM IT & Expenditure average (income total) & Miscellaneous & Yes & Yes & 1 \\
\hline 193 & $\begin{array}{l}\text { TUR GM I } \\
\text { TUT }\end{array}$ & $\begin{array}{l}\text { Expenditure average international tourists } \\
\text { (income total) }\end{array}$ & Miscellaneous & Yes & Yes & 1 \\
\hline 194 & TUR GM ET & Expenditure average (expenditure total) & Miscellaneous & Yes & Yes & 1 \\
\hline 195 & $\begin{array}{l}\text { TUR GM E } \\
\text { TIT }\end{array}$ & $\begin{array}{l}\text { Expenditure average international tourists } \\
\text { (expenditure total) }\end{array}$ & Miscellaneous & Yes & Yes & 1 \\
\hline 196 & AUT & Production total automotive & Miscellaneous & Yes & Yes & 1 \\
\hline 197 & AUT CAM T & Sales to the public. Total automotive & Miscellaneous & Yes & Yes & 1 \\
\hline 198 & $\begin{array}{l}\text { AUT CAM } \\
\text { TT }\end{array}$ & Sales to the public. Total buses & Miscellaneous & Yes & Yes & 1 \\
\hline
\end{tabular}




\begin{tabular}{|c|c|c|c|c|c|c|}
\hline$\#$ & Short & Long & Block & $\log$ & SA & $T$ \\
\hline 199 & $\begin{array}{l}\text { AUT CAM } \\
\text { TN }\end{array}$ & Sales to the public. Total buses (national) & Miscellaneous & Yes & Yes & 1 \\
\hline 200 & $\begin{array}{l}\text { AUT CAM } \\
\text { TI }\end{array}$ & Sales to the public. Total buses (imported) & Miscellaneous & Yes & Yes & 2 \\
\hline 201 & INPC & National index of consumer prices & Prices & Yes & Yes & 1 \\
\hline 202 & INPC 4 & INPC clothing, footwear, and accessories & Prices & Yes & Yes & 2 \\
\hline 203 & INPC 5 & $\begin{array}{l}\text { INPC furniture, household appliances, and } \\
\text { accessories }\end{array}$ & Prices & Yes & Yes & 2 \\
\hline 204 & INPC 5 & INPC health and personal care & Prices & Yes & Yes & 2 \\
\hline 205 & INPC 6 & INPC transportation & Prices & Yes & Yes & 2 \\
\hline 206 & INPC S & INPC underlying & Prices & Yes & Yes & 2 \\
\hline 207 & INPC SM & INPC underlying goods & Prices & Yes & Yes & 2 \\
\hline 208 & INPP 21 & $\begin{array}{l}\text { National index of producer prices (INPP) } \\
\text { mining without oil }\end{array}$ & Prices & Yes & No & 1 \\
\hline 209 & INPP 22 & $\begin{array}{l}\text { INPP generation, transmission and distribution } \\
\text { of electricity, water and gas supply by } \\
\text { pipelines to the final consumer }\end{array}$ & Prices & Yes & Yes & 1 \\
\hline 210 & INPP 23 & INPP construction & Prices & Yes & No & 1 \\
\hline 211 & INPP $48-49$ & INPP transportation, post and storage & Prices & Yes & Yes & 2 \\
\hline
\end{tabular}

Log denotes logarithmic transformation, SA means seasonal adjustment, and $T$ if 1 denotes that $y_{t} \sim I(1)$ and 2 that $\Delta y_{t} \sim I(1)$

\section{References}

Ahn S, Horenstein A (2013) Eigenvalue ratio test for the number of factors. Econometrica 81(3):1203-1227

Alessi L, Barigozzi M, Capasso M (2010) Improved penalization for determining the number of factors in approximate factor models. Stat Probab Lett 80(1):1806-1813

Bai J (2003) Inferential theory for factor models of large dimensions. Econometrica 71(1):135-171

Bai J (2004) Estimating cross-section common stochastic trends in nonstationary panel data. J Econom 122(1):137-183

Bai J, Ng S (2002) Determining the number of factors in approximate factor models. Econometrica 70(1):191-221

Bai J, Ng S (2004) A PANIC attack on unit roots and cointegration. Econometrica 72(4):1127-1177

Bai J, Ng S (2007) Determining the number of primitive shocks in factor models. J Bus Econ Stat 25(1):52-60

Bai J, Ng S (2008) Large dimensional factor analysis. Found Trends Econom 3(2):89-163

Banerjee A, Marcellino M, Masten I (2013) Structural factor error correction models: cointegration in large-scale structural FAVAR models. Bocconi University and CEPR, Working Paper

Banerjee A, Marcellino M, Masten I (2014) Forecasting with factor-augmented error correction models. Int J Forecast 30(3):589-612

Barigozzi M, Lippi M, Luciani M (2016) Non-stationary dynamic factor models for large datasets. Finance and Economics Discussion Series 024

Boivin J, Ng S (2006) Are more data always better for factor analysis? J Econom 132(1):169-194

Bräuning F, Koopman SJ (2014) Forecasting macroeconomic variables using collapsed dynamic factor analysis. Int J Forecast 30(3):572-584

Breitung J, Choi I (2013) Factor models. In: Hashimzade N, Thorthon MA (eds) Handbook of research methods and applications in empirical macroeconomics. Edward Elgar, Cheltenham (UK) 
Caruso A (2015) Nowcasting Mexican GDP. ECARES Working Paper 2015-40

Chamberlain G, Rothschild M (1983) Arbitrage factor structure, and mean-variance analysis of large asset markets. Econometrica 51(1):1281-1304

Corona F, Poncela P, Ruiz E (2017a) Determining the number of factors after stationary univariate transformations. Empir Econ 53:351-372

Corona F, Poncela P, Ruiz E (2017b) Estimating non-stationary common factors: implications for risk sharing. UC3M Working Papers Statistics and Econometrics 17(09)

Dougherty S (2015) Boosting growth and reducing informality in Mexico. OECD Economics Department Working Papers 1188

Duy TA, Thoma MA (1998) Modeling and forecasting cointegrated variables: some practical experience. J Econ Bus 50(1):291-307

Eickmeier S, Ziegler C (2008) How good are dynamic factor models at forecasting output and inflation? A meta-analytic approach. J Forecast 27(3):237-265

Eickmeier S, Lemke W, Marcellino M (2014) Classical time-varying FAVAR models-estimation, forecasting and structural analysis. J R Stat Soc 178(3):493-533

Engle RF, Granger CWJ (1987) Co-integration and error correction: representation, estimation, and testing. Econometrica 55(1):251-276

Ergemen YE, Rodriguez-Caballero CV (2016) A dynamic multi-level factor model with long-range dependence. CREATES Research Paper 23

Forni M, Hallin M, Lippi M, Reichlin L (2000) The generalized dynamic-factor model: identification and estimation. Rev Econ Stat 82(4):540-554

Fuentes J, Poncela P, Rodrguez J (2015) Sparse partial least squares in time series for macroeconomic forecasting. J Appl Econom 30(4):576-595

Geweke J (1977) The dynamic factor analysis of economic time series. In: Aigner DJ, Goldberger AS (eds) Latent variables in socio-economic models. North-Holland, Amsterdam

Giannone D, Reichlin L, Small D (2008) Nowcasting: the real-time informational content of macroeconomic data. J Monet Econ 55(4):665-676

Gonzalo J, Granger CWJ (1995) Estimation of common long-memory components in cointegrated systems. J Bus Econ Stat 13(1):27-35

Hallin M, Liska R (2007) Determining the number of factors in the general dynamic factor model. J Am Stat Assoc 102:603-617

Hanson G (2010) Why isnt Mexico rich? J Econ Lit 48(4):987-1004

Hindrayanto I, Koopman SJ, de Winter J (2016) Forecasting and nowcasting economic growth in the euro area using factor models. Int J Forecast 32(4):1284-1305

INEGI (2016) Producto interno bruto de méxico durante el tercer trimestre de 2016. http://www.inegi.org.

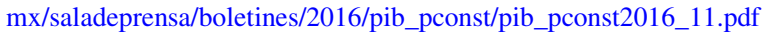

Johansen S (1988) Statistical analysis of cointegration vectors. J Econ Dyn Control 12(1):231-254

Johansen S (1991) Estimation and hypothesis testing of cointegrating vectors in Gaussian vector autoregressive models. Econometrica 59(1):1551-1580

Kapetanios G (2010) A testing procedure for determining the number of factors in approximate factor models with large datasets. J Bus Econ Stat 28(3):397-409

Kehoe T, Ruhl K (2010) Why have economic reforms in Mexico not generated growth? J Econ Lit 48(4):1005-1017

Kunst R, Neusser K (1997) Cointegration in a macroeconomic system. J Appl Econ 5(1):351-365

Lahiri K, Monokroussos G, Yongchen Z (2016) Forecasting consumption: the role of consumer confidence in real time with many predictors. J Appl Econ 31(7):1254-1275

Lütkepohl H (2006) New introduction to multiple time series analysis. Springer, New York

Marcellino M, Stock JH, Watson MW (2003) Macroeconomic forecasting in the euro area: country specific versus euro wide information. Eur Econ Rev 47(1):1-18

Onatski A (2010) Determining the number of factors from empirical distribution of eigenvalues. Rev Econ Stat 92(4):1004-1016

Panopoulou E, Vrontos S (2015) Hedge fund return predictability: to combine forecast or combine information? J Bank Financ 56:103-122

Peña D, Poncela P (2004) Forecasting with nonstationary dynamic factor models. J Econom 119(1):291-321

Reijer AHJ (2005) Forecasting Dutch GDP using large scale factor models. Netherlands Central Bank Working Paper 
Rodriguez-Pose A, Villarreal E (2015) Innovation and regional growth in Mexico: 2000-2010. Growth Change 46(2):172-195

Sargent TJ, Sims CA (1977) Business cycle modeling without pretending to have too much a priory economic theory. In: Sims CA (ed) New methods in business cycle research. Federal Reserve Bank of Minneapolis, Minneapolis

Schumacher C (2007) Forecasting German GDP using alternative factor models based on large datasets. J Forecast 26(4):1167-1179

Schwellnus C (2011) Macroeconomic and structural policies to further stabilise the Mexican economy. OECD Economics Department Working Papers 906

Stock JH, Watson MW (1988) Testing for common trends. J Am Stat Assoc 83(1):1097-1107

Stock JH, Watson MW (2002a) Forecasting using principal components from a large number of predictors. J Am Stat Assoc 97(1):1169-1179

Stock JH, Watson MW (2002b) Macroeconomic forecasting using diffusion indexes. J Bus Econ Stat 20(1):147-163

Stock JH, Watson MW (2005) Implications of dynamic factor models for VAR analysis. NBER Working Paper 11467

Stock JH, Watson MW (2011) Dynamic factor models. In: Clements MP, Hendry DF (eds) Oxford handbook of economic forecasting. Oxford University Press, Oxford

Vahid F, Engle RF (1993) Common trends and common cycles. J Appl Econom 8(1):341-360

Wilms I, Croux C (2016) Forecasting using sparse cointegration. Int J Forecast 32(4):1256-1267

World Bank (2016a) Mexico overview. World Bank, Washington, DC. http://www.worldbank.org/en/ country/mexico/overview\#3

World Bank (2016b) World development indicators. World Bank, Washington, DC. http://data. worldbank.org/data-catalog/world-development-indicators 